American University Washington College of Law

Digital Commons @ American University Washington College of

Law

Articles in Law Reviews \& Other Academic Journals

Scholarship \& Research

2015

Fracking, Federalism, and Private Governance

Amanda Leiter

Follow this and additional works at: https://digitalcommons.wcl.american.edu/facsch_lawrev

Part of the Environmental Law Commons, and the Oil, Gas, and Mineral Law Commons 


\title{
FRACKING, FEDERALISM, AND PRIVATE GOVERNANCE
}

\author{
Amanda C. Leiter*
}

The United States is in the midst of a natural gas boom, made possible by advances in drilling and extraction technologies. There is considerable disagreement about the relative benefits and costs of the boom, but one thing is certain: it has caught governments flat-footed. The federal government has done little more than commission a study of some associated public health and environmental risks and propose regulations for drilling on federal land. States have moved faster to address natural gas risks, but with little consistency or transparency.

Numerous private organizations are stepping into the resulting governance gaps with information-gathering and standards-setting efforts. As this Article documents, these private organizations are performing the functions once assigned to states in socalled "laboratory federalism": developing innovative governance approaches andperhaps more importantly-catalyzing the horizontal and vertical diffusion of successful governance strategies. In some cases, the likely outcome is a public governance regime with private origins; in others, private entities are likely to continue to play a role even as public entities enter the frame, creating a hybrid regime. Both outcomes highlight the need for process reforms to increase private entities' openness, balance, and accountability. Familiar administrative procedures followed by public agencies offer one model for such reforms, but at least in the natural gas context, those procedures may be less effective for private entities than for the public agencies for which they were designed.

I. An Introduction to the Technology and Risks of Unconventional

Gas Extraction ..................................... 112

A. The Technology .............................. 112

B. The Risks ................................. 115

II. An Introduction to Gas Governance Efforts ................. 119

A. The Scope of Public Governance..................... 119

B. The Scope of Private Governance .................. 126

1. Information Gathering and Dissemination ........... 127

2. Standards Development: An Introduction to the Players ..................................

3. Standards Development: A Comparison of Ongoing Efforts ..................................

4. Standards Implementation and Enforcement......... 134

III. Private Environmental Governance Theory ................ 134

A. The Hurdles Facing Public Environmental Governance...... 135

B. The Hurdles in Context: Public Governance of Natural Gas Risks....................................

\footnotetext{
* Associate Professor of Law, American University Washington College of Law. Many thanks to Dean Claudio Grossman and the American University Washington College of Law for generously supporting this project, and to participants in the 2014 Sabin Colloquium on Innovative Environmental Law Scholarship at Columbia Law School for their helpful insights. Thanks also to Jonas Anderson, Louis Cohen, Kate Debrason, Sara Falk, Amanda Frost, Abbe Gluck, Heather Hughes, Rob Kelsey, Kati Kovacs, Drew Lavine, Ben Leff, Elizabeth Lewis, Zachary Mason, Jennifer Mueller, Jeanne Paben, Cymie Payne, Justin Pidot, Jess Portmess, Adeen Postar, Ryan Rowberry, Sambhav N. Sankar, Richard Sears, David Snyder, Stephen Vladeck, Lindsay Wiley, and Hannah Wiseman for, in varying measures, terrific research assistance, sound advice, good edits, and honest critiques.
} 
C. Private Environmental Governance: A Partial Solution?..... 141

IV. Interactions Between Private and Public Gas Governance ....... 149

A. The Positive Story .............................. 150

B. Negative Spillover Effects ..................... 152

Conclusion ......................................... 154

Appendix ......................................... 156

\section{INTRODUCTION}

Improvements in horizontal drilling and hydraulic fracturing technologies have increased our ability to recover natural gas and oil from untapped reserves in shale and "tight" or impermeable sandstone layers miles underground. In his 2012 State of the Union Address, President Obama emphasized the need to develop these so-called "unconventional" health and safety of our citizens at risk," 2 but that task is proving more challenging than his easy rhetoric suggests. The natural gas boom is changing rural landscapes ${ }^{3}$ across America, bringing the promise of prosperity along with risks to human health and the environment.

As the boom progresses, and its benefits and risks come into ever-sharper focus, numerous questions arise about the appropriate governance response: What public health and environmental risks does the boom pose? Is further regulation necessary, or are existing laws sufficient? If new laws or regulations are necessary, what form should they take?

Scholars are beginning to address these questions, ${ }^{4}$ with some prescribing specific law reforms and others debating the appropriate locus for those reforms-federal, regional, state, or local government. At present, though, the debate among these authors remains largely academic. Whatever form the ideal public governance regime might someday take, the present regime is largely characterized by federal inaction and by state opacity and heterogeneity. There is little sign that Congress will soon enact comprehensive legislation governing shale and tight gas extraction. Moreover, the oil and gas industry benefits from numerous statutory exceptions that curtail federal agencies' authority to address

\footnotetext{
${ }^{1}$ The term "unconventional gas" refers to gas "trapped underground by impermeable rocks, such as coal, sandstone and shale." FAQs: Natural Gas, INT'L ENERGY AGENCY, http://perma.cc/JT5R$\mathrm{KC} 2 \mathrm{H}$. This Article concerns only two of the three main types of unconventional gas-shale gas and tight gas. The third, coal bed methane, is extracted using a somewhat different technology that is beyond the scope of this Article. For an explanation of the techniques used to extract coal bed methane, see generally All Consulting \& Mont. Bd. of Oil \& Gas Conservation, Coal Bed Methane Primer: New Source of Natural Gas-Environmental Implications (2004), http://perma.cc/HQ4Z-UD8L.

${ }^{2}$ Press Release, President Barack Obama, Remarks by the President in State of the Union Address (Jan. 24, 2012), http://perma.cc/PZ7M-JU3E.

${ }^{3}$ Some cities have also seen drastic changes. See, e.g., Increasing Drug Trade, Violence Mar Positive Effects of Bakken Boom, Brllngs GazerTe (Apr. 13, 2014), http://perma.cc/CF6UEJAW (describing the increase in crime in and near Williston, ND, accompanying the oil and gas boom).

${ }^{4}$ See infra text accompanying notes 74-84.
} 
natural gas risks under existing environmental and public health laws. ${ }^{5}$ On the state level, there is considerable legislative and regulatory activity, but much of it is opaque, and those efforts that are observable are still spotty. ${ }^{6}$

As a result, there is a significant public governance gap in the natural gas world and an opening for private governance efforts. Over the last few years, several large, national, nongovernmental organizations ("NGOs") have taken actions "designed to achieve traditionally governmental ends" related to natural gas development. These private entities' activities range from increasing the availability of information about extraction techniques and risks to reducing public health and environmental externalities. For example, the privately run website FracFocus ${ }^{8}$ serves as a clearinghouse for information on the chemicals used in individual exploration and extraction wells. Several private nonprofits, involving a range of industry and environmental stakeholders, seek to identify best practices for all or part of the gas extraction process. Examples include the American Petroleum Institute ("API"), ${ }^{9}$ the American Society for Testing and Materials ("ASTM"), ${ }^{10}$ the Center for Sustainable Shale Development ("CSSD"), " the Gas and Preservation Partnership ("GAPP"), ${ }^{12}$ and the State Review of Oil and Natural Gas Environmental Regulations ("STRONGER"). ${ }^{13}$ Lastly, some of these private entities are wrestling with the steps that must come after standards development: diffusion, implementation, and enforcement of identified best practices. CSSD, for example, recently announced that it is accepting applicants for a new, independent, third-party verification program, which will assess applicants' compliance with CSSD's performance standards and award compliance certifications. ${ }^{14}$

In the environmental arena, as elsewhere, attitudes toward these kinds of private governance efforts are rarely nuanced. Supporters argue that private regimes create opportunities for NGOs and industry participants to work together to identify cost-effective approaches to risk reduction - that is, opportunities to address environmental and health harms while also staving off more onerous and less carefully tailored government regulation. ${ }^{15}$ Supporters also

\footnotetext{
${ }^{5}$ See infra text accompanying notes $90,108-11$.

${ }^{6}$ See infra text accompanying notes 115-19.

${ }^{7}$ Michael P. Vandenbergh, Private Environmental Governance, 99 CoRnell L. REv. 129, 146 (2013) (defining private environmental governance).

${ }^{8}$ FRACFocus, http://perma.cc/UE6X-LREE.

${ }^{9}$ Am. Petrol. Inst., Overview of Industry Guidance/Best Practices on Hydraulic FracTURING (HF), (2012) [hereinafter API, OVERVIEW OF INDUSTRY GUIDANCE], http://perma.cc/ LM5N-XS39.

${ }^{10}$ Doug Clauson, Hydraulic Fracturing: New ASTM International Subcommittee to Develop Needed Standards, ASTM Int'L StandardiZation News (Nov./Dec. 2012), http://perma.ccl LL7G-Y8CK.

11 Performance Standards, CTr. for Sustanable Shale Dev., http://perma.cc/SMS2-H49G.

${ }^{12}$ Gas \& Preservation P'ship, http://perma.cc/X2LA-KXZM.

${ }^{13}$ State Rev. of Oil \& Natural Gas Envtl. Regulations, http:/perma.cc/5W82-9X4J.

${ }_{14}^{14}$ Certification, Ctr. for Sustainable Shale Dev., http://perma.cc/HXT6-G6S5.

${ }^{15}$ See generally Tracey M. Roberts, Innovations in Governance: A Functional Typology of Private Governance Institutions, 22 Duke EnvTL. L. \& PoL'Y F. 67, 77-135 (2011) (identifying the roadblocks to government regulation of certain risks and the variety of private governance institutions that arise to fill the resulting regulatory gap).
} 
emphasize that private regimes can complement or even catalyze development of public governance strategies. ${ }^{16}$ Opponents, by contrast, see any private and voluntary effort at self-governance as inherently self-serving and suspect "greenwashing"-industry players' attempt to improve their public images while staving off government regulation and thus avoiding the costs of real risk reduction. ${ }^{17}$ As always, the reality lies between these extremes and depends on such factors as the structure of the relevant industry, the adequacy of any federal or state regulation of the industry, the details of the private governance regime (such as the inclusion of rigorous compliance mechanisms), ${ }^{18}$ and the characteristics of the risks that the private entity seeks to address.

In exploring these factors, the growing literature on private environmental governance ${ }^{19}$ builds on both public choice insights, ${ }^{20}$ including such issues as capture and free riding, ${ }^{21}$ and work that explores the degree to which states in our federal system serve as "laborato[ries]" of policy development. ${ }^{22}$ From these roots, private environmental governance scholars have offered a typology

\footnotetext{
${ }^{16}$ See id. at 69.

${ }^{17}$ See, e.g., Dory Hippauf, GREENWASHED Center for Sustainable Shale Development, No FRACKING WAY (June 13, 2013), http://perma.cc/8N5E-CG5L; Roberts, supra note 15, at 70-71 (noting that when private governance entities "preempt formal regulation and compete with one another for participants, consumers, investors, and regulatory space," the "[c]onsequences include 'greenwashing' or misinformation and fraud in meeting consumers' and investors' social and environmental preferences"). But see Vandenbergh, supra note 7, at 137 ("A recent comprehensive review of empirical research on private environmental certification systems . . . finds evidence of substantial positive impacts on corporate environmental behavior at the global and local levels. This conclusion is consistent with a number of studies of other forms of private environmental governance. The effects on corporate behavior are better established than the effects on environmental quality, but early indications suggest that some private governance programs have important effects on environmental quality as well.").

${ }^{18}$ For a discussion about the effectiveness of voluntary compliance programs, see generally Nicole Darnall \& Stephen Sides, Assessing the Performance of Voluntary Environmental Programs: Does Certification Matter?, 36 PoL'y STUD. J. 95 (2008).

${ }^{19}$ Among the prior works in this area are Vandenbergh, supra note 7 , at 162 , which identifies those few papers that have addressed the subject of private environmental governance regimes, including Michael P. Vandenbergh, The Private Life of Public Law, 105 CoLum. L. Rev. 2029, 2030-32 (2005); Errol Meidinger, Private Import Safety Regulation and Transnational New Governance, in IMPORT SAFETY 233 (Coglianese et al. eds., 2009); Eric W. Orts, Climate Contracts, 29 VA. EnVtL. L.J. 197 (2011); Heather Hughes, Enabling Investment in Environmental Sustainability, 85 IND. L.J. 597 (2010); Annecoos Wiersema, A Train Without Tracks: Rethinking the Place of Law and Goals in Environmental and Natural Resources Law, 38 ENVTL. L. 1239 (2008).

${ }^{20} \mathrm{~A}$ thorough review of this important area of scholarship is well beyond the scope of this Article. For an overview of work on public choice insights, see, e.g., Maxwell L. STEARns \& Todo J. Zywicki, Public Choice Concepts and Applications in Law (2009).

${ }^{21}$ See, e.g., Bruce H. Kobayashi \& Larry E. Ribstein, Law as Product and Byproduct, 9 J.L. Econ. \& PoL'Y 521, 527 (2013); Roberts, supra note 15, at 77-78 (discussing the breakdown in public regulatory activity at each stage of the lawmaking process). For further examples of existing work on these topics, see infra notes 193-94 and accompanying text.

${ }^{22}$ New State Ice Co. v. Liebmann, 285 U.S. 262, 311 (1932) (Brandeis, J., dissenting) ("It is one of the happy incidents of the federal system that a single courageous state may, if its citizens choose, serve as a laboratory; and try novel social and economic experiments without risk to the rest of the country."). For a critique of this idea, see, e.g., Susan Rose-Ackerman, Risk Taking and Reelection: Does Federalism Promote Innovation?, 9 J. Legal Stud. 593, 594, 610-11 (1980). For further examples of existing work in this area, see infra notes 204-1 1 and accompanying text.
} 
of hybrid governance institutions and begun to explore the ways that private efforts can complement, substitute for, or stymie public efforts to address environmental harms. ${ }^{23}$ In essence, these scholars assert that private entities can innovate when states do not (or cannot); that these policy innovations can migrate into public law; and finally, that as a result, privately developed policy innovations can help overcome some dysfunctions of public governance. ${ }^{24}$

The natural gas boom offers an unusual opportunity to evaluate these arguments in real time, because there is a public governance gap, and private governance efforts are ongoing. As yet, however, there is no systematic exploration of private entities' work to address the public health and environmental risks of the boom. ${ }^{25}$ This Article begins the discussion.

Part I offers an introduction to the technological complexity of horizontal drilling and hydraulic fracturing, and the associated public health and environmental risks. Part II then documents the extent of (and gaps in) federal and state regulatory regimes and introduces the private governance players. ${ }^{26}$ Part III briefly reviews the roots and contours of private environmental governance theory, illustrating each concept with examples of private natural gas governance. Part III also argues that while some private entities have adopted process reforms similar to the processes of public agencies, those reforms are unlikely to be as effective in the private context as they are in the public context.

Part IV then considers the relationship between private and public governance in the context of the natural gas boom. Theorists have observed that the efforts of private entities could have either positive or negative spillover effects for the development of sound public governance. Part IV first outlines those potential effects and then evaluates which effects are likely to predominate in

${ }^{23}$ See, e.g., Kobayashi \& Ribstein, supra note 21 , at 525 (discussing ways to use private lawmaking as a solution to the breakdown of public governance); Vandenbergh, supra note 7, at 146 (surveying private entities' contributions to environmental governance); Roberts, supra note 15 (offering a typology of private institutions and discussing the varied ways that private entities can contribute to effective governance); Jody Freeman, The Private Role in Public Governance, 75 N.Y.U. L. REv. 543, 543, 548 (2000) (asserting that governance is a negotiated relationship between private and public actors); Rena I. Steinzor, Reinventing Environmental Regulation: The Dangerous Journey from Command to Self-Control, 22 HARv. EnvTL. L. Rev. 103, 104 (1998) (discussing the perils of transitioning from "command and control" rules to private selfgovernance).

${ }^{24}$ But see Kobayashi \& Ribstein, supra note 21 , at 525 (identifying two reasons why private lawmaking, too, may not occur at an efficient level).

${ }^{25}$ Exceptions include Hannah J. Wiseman, The Private Role in Public Fracturing Disclosure and Regulation, 3 Harv. Bus. L. Rev. Online 49 (2013), perma.cc/z5ML-YFKM, and David B. Spence, Corporate Social Responsibility in the Oil and Gas Industry: The Importance of Reputational Risk, 86 Chi.-Kent L. Rev. 59 (2011). See also Hari M. Osofsky \& Hannah Wiseman, Hybrid Energy Governance, U. ILL. L. Rev. (forthcoming 2014) (discussing the Delaware River Basin Commission's work to address drilling and fracturing risks within the Delaware River watershed).

${ }^{26}$ This Article focuses on the activities of six entities: FracFocus, ASTM, CSSD, STRONGER, GAPP, and API. This list is representative rather than comprehensive. Other private entities active on natural gas issues include the Groundwater Protection Council, Groundwater Prot. CouncIL, http://perma.cc/5NS3-6MF3; the Natural Gas Supply Association, Natural Gas SuPPLY Ass' $\mathrm{N}$, http://perma.cc/G85H-RKGW; and various environmental groups, see, e.g., Sierra Club's Position on Hydraulic Fracturing, SierRa Club Allegheny GRP., http://perma.cc/Y54S-3WVJ. 
the gas context. Specifically, Part IV begins by supposing a possible end-state for hydraulic fracturing governance: a purely public, cooperative federalism regime, in which the federal government sets minimum standards for safe and clean gas production, and the states enjoy some leeway to determine how best to implement those standards. Part IV then considers the extent to which private gas governance entities are promoting or could promote development of such a regime, concluding on a less-than-optimistic note. On the one hand, private gas governance entities are important sources of new information and ideas, and they serve as vectors for the broader dissemination of existing information and ideas. Our developing gas governance regime thus owes a debt to the work of these entities. As might be expected, however, there are caveats. The proliferation of private entities and divergent, privately developed standards may impede development of a single set of federal minimum standards for hydraulic fracturing. Then too, even with the reforms noted in Part III, private gas governance entities are not particularly well structured to promote transparency, representativeness, and public accountability. As a result, both the information they gather and the policy innovations they develop raise fairness and democratic legitimacy concerns.

\section{An Introduction to the Technology and Risks of UnCONVENTIONAL Gas Extraction}

To assess the private environmental governance efforts in the natural gas arena, one must have some background understanding of unconventional gas extraction technology, the associated environmental and public health risks, and the extent of federal and state regulatory efforts. After a brief tour of those issues, Part I concludes with an introduction of six private governance players now working to address gas risks.

\section{A. The Technology}

Contrary to popular opinion, the basic technique of hydraulic fracturing is far from new. In the mid-1900s, Standard Oil introduced the technique, ${ }^{27}$ which involves injecting fluid and additives into the ground to break apart rock formations (or prop open existing fissures) and improve the flow of hydrocarbons. ${ }^{28}$ The process proved sufficiently effective that industry experts estimate it has been used in various forms in over one million domestic oil and gas wells in the intervening decades. ${ }^{29}$

\footnotetext{
${ }^{27}$ See Carl T. Montgomery \& Michael B. Smith, Hydraulic Fracturing: History of an Enduring Technology, J. Petro. Tech., Dec. 2010, at 26, 26.

${ }^{28}$ In the early years, companies used crude oil or a blend of crude and gasoline, mixed with sand, to fracture limestone formations. See id. at 27.

${ }^{29}$ See Susan L. Brantley \& Anna Meyendorff, Op-Ed., The Facts on Fracking, N.Y. TIMEs (Mar. 13, 2013), http://perma.cc/9NLX-7SMB (estimating one million wells have been drilled since the 1940s); About Natural Gas: Hydraulic Fracturing and Horizontal Drilling, ExxonMoBI, http:// perma.cc/YW5P-QWED (stating more than one million wells have been drilled in the last sixty
} 
In recent years, however, the pace of hydraulic fracturing has drastically increased due to technological breakthroughs that allow application of the basic technique to release natural gas and oil from porous, but relatively impermeable, shale or tight sandstone ("tight sands") layers deep underground. The modern process, known as "slickwater" fracturing, ${ }^{30}$ varies depending on location, geology, and other factors. In general terms, extraction companies now have the ability to employ computerized, 3-D imaging tools to locate gas deposits and natural fractures in thin, horizontal, shale or tight sands layers more than a mile underground; ${ }^{31}$ drill vertical wells down to those layers; ${ }^{32}$ turn remotelycontrolled, diamond-studded drill bits; and then drill horizontally through the shale or tight sands layers for thousands of feet perpendicular to the original well. ${ }^{33}$

After each phase of the drilling, casing - a series of steel drill pipes, each over thirty-feet long-is inserted into the hole and cemented into place. ${ }^{34}$ Each casing must be inserted through the one above it, so these casings necessarily get successively smaller in diameter as the well deepens. When all stages of drilling are complete, the result is a closed, approximately-L-shaped series of telescoping drill casings, cemented into a hole that, in many cases, extends several miles vertically into and then horizontally through the ground.

In a typical shale or tight gas well, the drilling company then uses explosive charges to perforate the steel casing in short sections of the horizontal portion of the well, in areas where data collected during drilling indicates that the impermeable layer surrounding the well is saturated with gas or oil. Next is the step that most captures the public imagination and raises fears: the "frac job," in which huge volumes of water-on the order of four and a half million gallons for a well in the Marcellus region in the northeastern United States, for example ${ }^{35}$-are pumped down the well, out through the perforations in the cas-

years). See also Montgomery \& Smith, supra note 27 , at 26 (indicating that 2.5 million wells have been hydraulically fractured worldwide over the same time period).

${ }^{30}$ Hannah Wiseman, Risk and Response in Fracturing Policy, 84 U. CoLo. L. REv. 729, 753-54 (2013) ("[A]lthough fracturing is an old practice, it is distinctly new in two important ways. First, the specific practice of slickwater hydraulic fracturing has introduced new processes to old fracturing techniques. Higher water use in fracturing requires, for example, larger water withdrawals .... Second, slickwater fracturing has enabled the development of thousands of new oil and gas wells in the United States." (citations omitted)).

${ }^{31}$ In the Marcellus Shale, for example, "vertical drilling ranges from 5,000 to 9,000 feet below ground." Resources: Maps and Graphics, Penn State Marcellus Ctr. for Outreach \& Res., http://perma.cc/7CZ7-475U.

${ }^{32}$ Some characterize these layers as the fossil fuel-saturated "filling in [the] Oreo cookie" of bedrock. Thomas W. Merrill \& David M. Schizer, The Shale Oil and Gas Revolution, Hydraulic Fracturing, and Water Contamination: A Regulatory Strategy, 98 MinN. L. Rev. 145, 154 (2013).

${ }^{33}$ See, e.g., Alex Trembath et al., Breakthrough Inst., Where the Shale Gas Revolution Came From: Government's Role in the Development of Hydraulic Fracturing in Shale (2012), http://perma.cc/S2MM-XJGE.

${ }^{34}$ George E. King, Soc'y of Petrol. Eng'rs, Hydraulic Fracturing 101: What Every RepRESENTATIVE, ENVIRONMENTALIST, REgulator, REPORTER, INVESTOR, UnIVERSITY RESEARChER, Neighbor, and Engineer Should Know About Estimating Frac Risk and Improving Frac Performance in Unconventional Gas and OIL Wells (2012), http://perma.cc/GQW9-6YEG. ${ }^{35}$ Jesse Jenkins, Energy Facts: How Much Water Does Fracking for Shale Gas Consume?, THE EnERgY Collective (Apr. 6, 2013), http://perma.cc/ZK5C-XC7P. 
ing, and into the surrounding shale or tight sands, where the pressurized fluid fractures the rock. ${ }^{36}$

To improve the flow of hydrocarbons through the resulting fissures, the drilling company mixes additives into this water, including chemicals to control the growth of bacteria and scales in the well, fine sand or other particulate "proppants" to prop open the cracks in the shale once the water is withdrawn, and lubricants ${ }^{37}$ to make the water flow more easily under pressure. ${ }^{38}$ The basic formulation of slickwater for shales includes about $98-99 \%$ water, 1-2\% proppants, and less than $0.1 \%$ chemical additives of various sorts. ${ }^{39}$

After the rock is fractured, the pumps are turned off. At this point, the well can be temporarily abandoned if economic conditions persuade the production company to wait to produce the gas. Temporary abandonment involves plugging the well with cement that can readily be drilled if and when the price of gas rises to a point that production is feasible.

When the production company is ready to produce gas from the well, activity shifts to the "production phase," which is largely automated. The company restores the ground around the drilling site, leaving some processing equipment at the wellhead, along with oil or gas collection lines to transport the product away from the well..$^{40}$ The typical onsite equipment includes a system of tubes and valves, known as a "Christmas tree," which controls the flow of gas.

Importantly, both the frac job and the production phase produce considerable wastewater. Initially, when the drill pumps are turned off, the underground rock formation "relaxes" and manmade fractures close to the extent allowed by the proppant. This process drives a large volume of "flowback" water out of the well..$^{41}$ In addition, over the life of the well, production of gas generates a waste stream, generally known as "produced water." Both waste streams comprise the water and chemicals that were pumped down the well during fracturing, additional water that had been trapped in the formation, salt, hydrocarbons, naturally occurring radioactive material ("NORM"), and other compounds from the formation. ${ }^{42}$

Next is the "processing" step, which involves separating the gas from any water or other impurities prior to compressing and transporting it (via pipeline)

\footnotetext{
${ }^{36}$ See generally Graham Roberts, Mika Gröndal \& Bill Marsh, Extracting Natural Gas from Rock, N.Y. Times (Feb. 26, 2011), http://perma.cc/JA7Q-VLDP.

${ }^{37}$ The lubricants are the source of the term "slickwater" fracturing that is sometimes used to describe this process. See KING, supra note 34, at 7.

${ }^{38}$ See, e.g., Chemical Use in Hydraulic Fracturing, FRACFocus, http://perma.cc/5VZG-L25M. ${ }^{39} \mathrm{ld}$.

${ }^{40}$ See Wiseman, supra note 30, at 757; see also Completed Well Pads and Equipment, EnCANA, http://perma.cc/5T58-BWR3

${ }^{41}$ Email from Richard Sears, Consulting Professor, Stanford University, to author (Aug. 22, 2013) (on file with author). Only a fraction of the introduced volume flows back, however-as little as $5 \%$ in the Haynesville Shale on the Gulf Coast, and up to as much as $50 \%$ in the Marcellus. The remainder of the water is trapped and held in the small pores and microfractures of the shale deep underground. See KING, supra note 34, at 10.

${ }^{42}$ See KING, supra note 34 , at 10.
} 
to its ultimate destination ${ }^{43}$ Finally, when the well is drawn down to the point that production is no longer economical, permanently closing or "abandoning" it requires removal of the remaining equipment and insertion of a more permanent type of cement that will, in theory, withstand the test of time-the ravages of water and ice, any seismic activity, and any future human activities around the well site (including future well-drilling efforts). ${ }^{44}$

\section{B. The Risks}

The rewards of this technologically extraordinary process are significant and largely self-evident. The promise of unconventional extraction techniques enabled the United States to increase its estimated natural gas reserves ${ }^{45}$ by $75 \%$ in just seven years, from 2004 to $2011 .{ }^{46}$ The U.S. Energy Information Administration projects that domestic gas production ${ }^{47}$ will increase by $44 \%$ between 2011 and 2040, due almost entirely to expanded shale gas extraction. ${ }^{48}$ Industry proponents tout the new jobs this production will support, the advantages of domestic energy production in light of current political realities in the Middle East, ${ }^{49}$ and, not least, the environmental benefits of natural gas itself, which burns more completely and cleanly than coal..$^{50}$

${ }^{43}$ Well Completion, NATURALGAs.org, http://perma.cc/MJL4-PV9P.

${ }^{44}$ See generally J. Daniel Arthur et al,, Plugging and Abandonment of Oil and Gas Wells (Nat'I Petrol. Council N. Am. Res. Dev. Study, Working Document Paper No. 2-25, 2011), http://perma .cc/4TGM-B3ZH (describing the risks posed by abandoned wells and some steps that can be taken at the time of abandonment to reduce those risks).

${ }^{45}$ The Energy Information Administration defines natural gas "reserves" as the "[e]stimated quantities of [natural gas] that analysis of geologic and engineering data demonstrates with reasonable certainty are recoverable under existing economic and operating conditions. The location, quantity, and grade of the energy source are usually considered to be well established in such reserves." Glossary, U.S. ENERGY INFO. ADMIN., http://perma.cc/6VMJ-LDUD.

${ }^{46}$ Richard J. Pierce, Jr., Natural Gas: A Long Bridge to a Promising Destination, 32 Utah EnvtL. L. REv. 245, 246 (2012).

${ }^{47}$ The Energy Information Administration defines natural gas "production" as the "[t]he volume of natural gas withdrawn from reservoirs less" volumes that are returned to the reservoirs or are otherwise not salable for various reasons. Glossary, supra note 45.

${ }^{48}$ See Energy in Brief: What Is Shale Gas and Why Is It Important?, U.S. ENERGy INFo. AdMIN., http://perma.cc/4Z6L-SLS3.

${ }^{49}$ The White House itself makes this argument. See, e.g., Jason Furman \& Gene Sperling, Reducing America's Dependence on Foreign Oil as a Strategy to Increase Economic Growth and Reduce Economic Vulnerability, THE WHITE House BLOG (Aug. 29, 2013), http://perma.cc/C3LT9K8T. Importantly, though, natural gas and oil serve very different purposes in our current economy; we rely on natural gas to produce electricity and foreign oil to power our transportation sector. See, e.g., U.S. Energy Info. Admin., Annual Energy Review 2011, at 37 fig.2.0 (2012), http://perma.cc/R95-7YNA (indicating that in 2011, petroleum supplied 93\% of the energy used by the U.S. transportation sector, while natural gas supplied only $3 \%$ ). Unless we radically increase the percentage of natural gas-fueled cars and trucks on American roads (as the White House seems to advocate, see Furman \& Sperling, supra), natural gas is more likely to displace domestic coal rather than petroleum. See, e.g., Marin Katusa, Shale Gas Takes on Coal to Power America's Electrical Plants, ForBes (May 30, 2012), http://perma.cc/U6BD-6976.

${ }_{50}$ See, e.g., Natural Gas and the Environment, NATURALGAS.ORG, http://perma.cc/B958-KXYP ("Natural gas is the cleanest of all the fossil fuels .... Composed primarily of methane, the main products of the combustion of natural gas are carbon dioxide and water vapor, the same compounds we exhale when we breathe. Coal and oil are composed of much more complex molecules, 
Significant uncertainty surrounds these alleged benefits, but even more contentious and uncertain are the public health and environmental risks of the resulting natural gas boom, some of which may not yet be evident. Thus far, the public discussion of these risks has largely centered on one stage of well development-the frac job itself, during which large volumes of pressurized water and chemicals are injected into the ground to fracture previously impermeable rock layers, thereby creating a potential conduit for groundwater pollution. ${ }^{51}$ That focus is natural given the terminology. Phrases like "horizontal drilling" and "hydraulic fracturing" conjure vivid images of man-made cracks through which contaminants like gas and oil can flow up from the depths and into our drinking water supplies. To some degree, industry opponents have played on those fears, abbreviating "hydraulic fracturing" not to "fracing," as the industry prefers, but to "fracking," a negative-sounding "slur" that "obviously calls to mind other less socially polite terms." ${ }_{52}$ At the same time, industry proponents have also benefited from the public focus on the risks associated with fluid injection, because that narrow focus has distracted attention from the health and environmental threats posed by other stages of gas development, and by the sheer magnitude of the gas boom.

In fact, risks arise not only during the fluid injection or fracturing stage of unconventional gas extraction, but also at all other exploration and well-development steps, "including constructing a well pad and access road, drilling and casing (lining) a well, and storing and disposing of drilling and fracturing wastes, among many other steps." 53 Research into these risks is underway all over the country, with risks observed in at least eight categories: water use, water pollution, air pollution, climate change, worker health and safety, earthquake safety, land and wildlife disruption, and community dislocation.

Water use issues principally arise in arid areas such as the desert Southwest, ${ }^{54}$ where drilling competes with agricultural and municipal water uses, and may stress aquatic ecosystems. ${ }^{55}$ Water pollution, meanwhile, follows two principal pathways. First, if fracturing chemicals or diesel fuels spill, or the large

[which] means that when combusted, coal and oil release higher levels of harmful emissions, including ... nitrogen oxides (NOx), . . sulfur dioxide (SO2) . . [and] ash particles . ... The combustion of natural gas, on the other hand, releases very small amounts of sulfur dioxide and nitrogen oxides, virtually no ash or particulate matter, and lower levels of carbon dioxide, carbon monoxide, and other reactive hydrocarbons.").

${ }_{51}$ See Wiseman, supra note 30 , at 736.

52 Jonathan Fahey, No Energy Industry Backing for the Word 'Fracking', YAHOO! NEws (Jan. 26, 2012), http://perma.cc/HA69-D8K2 (quoting Kate Sinding, Senior Attorney at the Natural Resources Defense Council).

${ }^{53}$ See generally Wiseman, supra note 30 , at 736 (detailing risks at all stages of tight gas development).

${ }^{54}$ Water use also can temporarily stress aquatic life even in water-rich areas, if too many water withdrawals occur in a short space of time. See, e.g., Press Release, Susquehanna River Basin Commission, 37 Water Withdrawals for Natural Gas Drilling and Other Uses Suspended to Protect Streams (June 28, 2012), http://perma.cc/C85V-M6BT (announcing the suspension of "37 separate water withdrawals . . . due to localized streamflow levels dropping throughout the Susquehanna basin").

55 Vikram Rao, Shale Gas: The Promise and the Peril 45-50 (2012); Wiseman, supra note 30 , at 776 . 
quantities of flowback and produced water are improperly stored or otherwise mishandled, then the resulting runoff can contaminate surface water bodies. ${ }^{56}$ Second, if drilling fluids or hydrocarbons migrate through existing or manmade rock fractures (as some fear ${ }^{57}$ ) or leak from ground storage pits or improperly sealed wells (perhaps a more realistic and serious eventuality ${ }^{58}$ ), those contaminants may leak into groundwater aquifers. ${ }^{59}$

Air pollution, too, can be a significant issue in areas of heavy drilling, where heavy diesel trucks come and go, drilling machinery runs constantly, volatile organic compounds evaporate from onsite storage tanks, and escaping hydrocarbons must be either vented to the atmosphere or "flared" (that is, burned as they leave the well head). ${ }^{60}$ Thus air and water pollution both pose an obvious threat to the health and welfare of nearby populations, depending on the nature and quantity of the pollutants. ${ }^{61}$

The climate change consequences of the natural gas boom are heavily debated. Indeed, some put climate consequences on the "benefit" side of natural gas's balance sheet, touting "the low carbon content of natural gas relative to other fossil fuels" and arguing that, as a result, natural gas could serve as "a 'bridge' to a low-carbon future." 62 Others counter, though, that devoting resources to improving the infrastructure for natural gas development, transport, and use could reduce investment in alternative energy technologies, which have even smaller climate footprints..$^{63}$ Moreover, if significant amounts of unburned

\footnotetext{
${ }^{56}$ To give just one example, any wastewater held on site must be stored in a waste pond that is well lined (to prevent seepage) and adequately constructed (to prevent leakage during flooding events).

${ }^{57}$ See, e.g., Chris Tackett, Natural Gas: 6 to 12 Percent of the Methane Produced is Leaking, Study Finds, TreeHUGGER (Aug. 9, 2013), http://perma.cc/YKK3-PUX7.

${ }^{58}$ See, e.g., Richard Fausset \& Neela Banerjee, Tests Warned of Cement Problems Before Well's Blowout: BP and Halliburton Were Aware of Them But Used It Anyway, an Investigative Commission Reports, L.A. TIMEs (Oct. 29, 2010), http://perma.cc/SXL6-KALF (citing findings of President Obama's special commission investigating the BP Deepwater Horizon spill); NEw Mexico Oll Conservation Div., Cases Where Ptt Substances Contaminated New Mexico's GROUNDWATER (2008), http://perma.cc/M2TU-3K35.

${ }^{59}$ RAO, supra note 55, at 35-44; Wiseman, supra note 30, at 770-75 (mishandling of flowback and produced water), 783-88 (improper casing), 761-65 (surface chemical spills); EPA's Study of Hydraulic Fracturing for Oil and Gas and Its Potential Impact on Drinking Water Resources, EPA, http://perma.cc/N4AQ-PGRZ.

${ }^{60}$ See Wiseman, supra note 30, at 805-07; Oil and Natural Gas Sector: New Source Performance Standards and National Emission Standards for Hazardous Air Pollutants Reviews, 77 Fed. Reg. 49,490 (Aug. 16, 2012) (to be codified at 40 C.F.R. pts. 60, 63); Mead Gruver, Wyoming Air Pollution Worse Than Los Angeles Due to Gas Drilling, Huffington Post (Mar. 8, 2011), http:// perma.cc/Y5QS-4UYH.

${ }^{61}$ See, e.g., David Kelly, Study Shows Air Emissions Near Fracking Sites May Pose Health Risk, CU NewSROom (Mar. 19, 2012), http://perma.cc/N2U9-CFAE.

${ }^{62}$ MIT Energy Initiative, The Future of Natural Gas: An Interdisciplinary MIT Study 1 (2011), http://perma.cc/DNP9-W8NR.

${ }^{63}$ See Richard Harris, Could Cheap Gas Slow Growth of Renewable Energy?, NPR (Feb. 2, 2012), http://perma.cc/TA52-9Y22 (quoting Henry Jacoby, an economist at the Center for Energy and Environmental Policy Research at MIT, who warns " "we have to keep our eye on the ball longterm.' ... Wind and solar power are more expensive than natural gas, and though those prices have been coming down, they're chasing a moving target that has fallen fast: natural gas. 'It makes the prospects for large-scale expansion of those technologies more chancy.'"). See also RaO, supra note 55 , at $122-28$.
} 
methane leak into the atmosphere during well drilling, well completion, gas transport, or gas use, that leakage could undermine or even erase the supposed benefits of gas as a bridge fuel. ${ }^{64}$ Individual molecules of methane (" $\mathrm{CH}_{4}$ ") trap warming radiation far more effectively than the carbon dioxide molecules (" $\mathrm{CO}_{2}$ ") produced when coal and, to a lesser extent, gas are burned: "the comparative impact of [atmospheric] $\mathrm{CH}_{4}$ on climate change is over 20 times greater than [that of $\mathrm{CO}_{2}$ ] over a 100 -year period."65

As for worker health and safety, risks arise at all stages of gas production. They range from familiar occupational hazards, such as traffic and worksite accidents, to exposure to hazardous materials used on site or produced from deep underground. ${ }^{66}$ There is also developing evidence that workers exposed to the fine sand used as a proppant face an increased risk of the serious lung disease silicosis. ${ }^{67}$

Natural gas exploration and production activities may also pose a risk of increased earthquake activity. A recent Science article suggests that while the well-drilling and hydraulic-fracturing processes pose only "a low risk of inducing destructive earthquakes," the common practice of disposing of flowback and produced water by injecting them into existing deep wells "can induce larger earthquakes." ${ }_{68}$ Indeed, "several of the largest earthquakes in the U.S. midcontinent in 2011 and 2012 may have been triggered by nearby [wastewater] disposal wells," including a "magnitude 5.6 event in central Oklahoma that destroyed 14 homes and injured two people." 69

Then there is the land and wildlife disruption that results from the construction of well pads and access roads, and the installation of distribution pipe-

\footnotetext{
${ }^{64}$ There is a heated debate about the extent of this leakage. Compare Anna Karion et al., Methane Emissions Estimate from Airborne Measurements over a Western United States Natural Gas Field, 40 GeOPHYS. REs. LeTTERS 4393 (2013) (estimating considerable leakage), and Robert W. Howarth, Renee Santoro \& Anthony Ingraffea, Methane and the Greenhouse-Gas Footprint of Natural Gas from Shale Formations: A Letter, Climatic Change (Mar. 13, 2011), hittp://perma.cc/A5CUJXDE, with Philip Bump, The EPA Just Shook Up the Debate Over Fracking, ATLANTIC WIRE (Apr. 29, 2013), http://perma.cc/T48Y-W9KB ("New estimates from the EPA indicate that methane leakage from. natural gas production is substantially lower than previously believed."). The most recent scholarly contribution to this debate is decidedly ambivalent, finding higher emissions than the U.S. Environmental Protection Agency ("EPA") found, but nevertheless asserting that "system-wide [methane] leakage is unlikely to be large enough to negate climate benefits of coalto-[natural gas] substitution." Adam R. Brandt et al., Methane Leaks from North American Natural Gas Systems, 343 SCIENCE 733, 733 (2014).

${ }^{65}$ Overview of Greenhouse Gases: Methane Emissions, EPA, http://perma.cc/D6HT-ZM28.

${ }^{66}$ See generally Robert Iafolla, Four Fatalities Linked to Used Fracking Fluid Exposure During 'Flowback,' NIOSH Reports, BLOOMBERG BNA (May 20, 2014), http://perma.cc/M5RY-QPZA; John L. Adgate et al., Public Health Risks of Shale Gas Development, CATSKILl CrTIZENS For SAFE ENERGY (May 17, 2013), http://perma.cc/7R3F-SRVR.

${ }^{67}$ See Research Triangle Envtl. Health Collaborative, Shale Gas Extraction in North Carolina: Public Health Implications 12 (2012), http://perma.cc/C4SR-LVU9; Nell Greenfieldboyce, Sand from Fracking Could Pose Lung Disease Risk to Workers, NPR SHOTs (Mar. 29, 2013), http://perma.cc/HYX7-D465.

${ }_{68}$ William Ellsworth, Injection-Induced Earthquakes, 341 SCIENCE 142 (2013), http://perma.cc/ LZP5-W2UB (quotations appear in Structured Abstract in online version only).

${ }^{69}$ Id. See also Katie M. Keranen et al., Potentially Induced Earthquakes in Oklahoma, USA: Links Between Wastewater Injection and the 2011 Mw 5.7 Earthquake Sequence, 41 Geology 699 (2013).
} 
lines. These activities can create a visible blight, ${ }^{70}$ contribute to soil erosion if stormwater runoff is not properly managed, serve as a pathway for introduction of invasive species, ${ }^{71}$ and threaten cultural and historic sites. ${ }^{72}$

Finally, although the gas boom is revitalizing the economy in some towns and rural counties, the benefits are not always equally distributed and may come with a high cost to the local community. To take just one example, in the small town of Towanda, Pennsylvania, there are now "numerous high-paying drilling jobs," but "many residents lack the skills for them. . . Narrow country roads are crumbling under the weight of heavy trucks. With housing scarce and expensive, more residents are becoming homeless. Local services and infrastructure are strained." 73

\section{An Introduction to Gas Governance Efforts}

\section{A. The Scope of Public Governance}

As scholars and regulators learn more about the implications of the gas boom, they are beginning to recommend expansion of both research and regulatory efforts beyond the "frac job" itself to the full array of extraction activities and associated risks. ${ }^{74}$ They are also identifying policy reforms to address these broader risks, and debating the level of government at which these reforms should be implemented: federal, regional, state, or local.

Wrestling with the issue of water pollution risks, for example, Thomas W. Merrill and David M. Schizer suggest that an ideal regulatory program would combine (a) information-forcing disclosure requirements, (b) dynamic "best practices regulations" and (c) a set of default liability rules designed to encourage regulatory compliance, such as a presumptive defense to tort liability

\footnotetext{
${ }^{70}$ In this instance, a picture is worth a thousand words. A recent U.S. Geological Survey publication includes a striking picture of a once-forested landscape in McKean County, Pennsylvania, that is now crisscrossed with "roads, well pads, and pipelines related to natural gas development." E. Terry Slonecker et al., U.S. Geological Survey, Landscape Consequences of Natural Gas Extraction in Bradford and Washington Counties, Pensylvania, 2004-2010 3 fig.2 (2012), http://perma.cc/XX97-CX9N.

${ }^{71}$ Wiseman, supra note 30, at 795-96.

${ }^{72}$ Gas \& Pres. P'ship, Final Report from the Task Force on Cultural Resource Complance and Shale Gas Development and Operations (2013), http://perma.cc/4HCF-NYWM.

${ }^{73}$ Katharine Q. Seelye, Gas Boom Aids Pennsylvania, but Some Worry over the Risk, N.Y. TIMES (Oct. 14, 2011), http://perma.cc/TS43-FG5N. See also Scott Detrow, Five Years into Fracking Boom, One Pa. Town at a Turning Point, NPR (Jan. 14, 2013), http://perma.cc/ZX7H-EDYF ("You want to know how natural gas drilling has changed Towanda, Pennsylvania? Start with traffic. That's the first thing everyone who lives here will tell you about ... . Police Chief Randy Epler says his force has had its hands full . . . [with increased] DUIs, bar fights, [and] domestic issues .... A And rent soared too."). Professor Hannah Wiseman recently documented these and other risks based on a comprehensive review of recent violations of state environmental regulations at oil and gas sites in four heavy-drilling states. See Wiseman, supra note 30, at 747-53 nn.83-84 (surveying data on administrative violations from Louisiana, Michigan, New Mexico, and Texas).

${ }^{74}$ Wiseman, supra note 30 , at $808-15$.
} 
for companies that meet all applicable practice standards. ${ }^{75}$ They further advise "keeping the regulatory center of gravity in the states" to "ensure that the regulatory regime is both dynamic and tailored to local conditions." 76 David Spence, too, recommends that federal regulators allow the "process of learning and [regulatory] adaptation [to] play out mostly in the states" "7 because, in his view, most environmental externalities from unconventional gas development "are experienced locally," and those that cross state boundaries are, to a significant extent, "already adequately addressed by federal law."78

Other authors advocate a larger role for the federal government in addressing natural gas risks. Michael Burger, for example, notes that Spence's focus on the local effects of individual shale or tight gas operations ignores both the scale of the nationwide gas boom and the cumulative impacts of that boom on the "cultural and historic landscape" of "rural and small town America." 79 For Burger, those considerations are sufficient to render unconventional gas drilling a "matter of true, national concern." 80 Likewise, Robin Kundis Craig, Jody Freeman, and Hannah Wiseman see a central role for the federal government. Kundis Craig argues that the impacts of hydraulic fracturing on both water quantity and water quality obligate the federal government to play a "more dominant role" in policy development. ${ }^{81}$ Freeman touts the advantages of a cooperative federalism regime, in which the federal government sets baseline performance standards, but allows states some flexibility in deciding how to meet them. ${ }^{82}$ Wiseman makes a similar point, and further suggests that a federal entity could maintain a clearinghouse of information on state laws and industry performance standards, "to assist states in identifying the best regulatory options, ... remind the laggards of areas where improvement is needed and demonstrate the many variations in risk response." ${ }^{83}$ Wiseman and Osofsky also note the advantages of a regional governance approach, and of hybrid gov-

\footnotetext{
${ }_{76}^{75}$ Merrill \& Schizer, supra note 32, at 201-27.

${ }^{76} \mathrm{Id}$. at 151 .

${ }^{77}$ David B. Spence, Federalism, Regulatory Lags, and the Political Economy of Energy Production, 161 U. PA. L. Rev. 431, 508 (2013).

${ }^{78}$ Id. at $492-93$.

${ }^{79}$ Michael Burger, Response: Fracking and Federalism Choice, 161 U. PA. L. Rev. OnLine 150, 162-63 (2013).

${ }^{80}$ Id. at 159 (emphasis added).

${ }^{81}$ Robin Kundis Craig, Hydraulic Fracturing (Fracking), Federalism, and the Water-Energy Nexus, 49 IDAHO L. Rev. 241, 260 (2013).

82 Jody Freeman, Op-Ed., The Wise Way to Regulate Gas Drilling, N.Y. Times (July 5, 2012), http://perma.cc/YUM8-RVVB. Under this sort of "cooperative federalism" scheme-already in place in other contexts, including in the Surface Mining Control and Reclamation Act, 30 U.S.C. $\S \S 1234-1328$ (2012), which governs coal mining - the states "might be required to develop comprehensive [risk management] plans . . . based on best practices for disclosure, drilling location, well construction and wastewater treatment. States would implement and enforce the rules and issue and oversee the operating permits. The federal government could step in if states abdicated their responsibility." Freeman, supra.

${ }^{83}$ See Wiseman, supra note 30, at 736 ("[T] he debate has tended to focus on whether or not the injection of water and chemicals underground-the only stage of the process that is technically described as 'fracturing'-pollutes groundwater.").
} 
ernance organizations that "combine authority from more than one level of government," as well as from both public and private institutions. ${ }^{84}$

Some of the reforms suggested by scholars are already underway-particularly the broadening of regulatory focus away from the actual fracturing of rock layers and toward the full complement of natural gas risks. On the research front, for instance, both federal and state entities have recently undertaken studies that take a broad view of gas risks, ${ }^{85}$ and Maryland has imposed a de facto statewide moratorium on all shale and tight gas development pending completion of a full environmental review. ${ }^{86}$

Yet conspicuous public governance gaps remain. Consider Congress: apart from committee hearings ${ }^{87}$ and a 2009 request that the U.S. Environmental Protection Agency ("EPA") study the relationship between hydraulic fracturing and drinking water, ${ }^{88}$ the most recent significant congressional action with respect to unconventional gas extraction was deregulatory. In 2005, Congress passed the Energy Policy Act ${ }^{89}$ which includes language specifically exempting most kinds of hydraulic fracturing from the Safe Drinking Water Act's ("SDWA") otherwise pervasive regulation of any "subsurface emplacement of fluids by well injection." 90 Since then, House and Senate members have introduced several versions of a Fracturing Responsibility and Awareness of Chemicals ("FRAC") Act that would repeal the exemption and require some disclosure of the chemical constituents of fracturing fluids, but the bills have

\footnotetext{
${ }^{84}$ Osofsky \& Wiseman, supra note 25 , at 4.

${ }^{85}$ See, e.g., N.Y. State Dep't of Envtl. Conservation, Revised Draft: Supplemental Generic Environmental Impact Statement on the Oil, Gas, and Solution Mining RegulaTORY Program (2011) (surveying impacts of natural gas development in New York State on water resources, ecosystems and wildlife, air quality, greenhouse gas emissions, seismicity, human communities, and transportation infrastructure); Gabrielle Pétron et al., Hydrocarbon Emissions Characterization in the Colorado Front Range: A Pilot Study, 117 J. Geophysical RES. D04304 (2012) (using air pollution readings from a National Oceanic and Atmospheric Administration observation tower north of Denver to document methane leakage from oil and gas fields in northeastern Colorado).

${ }^{86}$ See Darryl Fears, Maryland Inches Closer to Decision Time on Hydraulic Fracturing, WASH. Post (Dec. 8, 2012), http://perma.cc/CX9W-8LE3 (indicating that under an executive order issued by Governor O'Malley, the Maryland Department of the Environment may not approve drilling permits until 2014, when a costly statewide study of drilling impacts is due to be completed, unless other data prove drilling safe sooner).

87 See, e.g., Shale Development: Best Practices and Environmental Concerns: Hearing Before the S. Comm. on Energy \& Natural Res., 113th Cong. (2013), http://perma.cc/YHV3-JQUK; Marcellus Shale Gas: Field Hearing before the S. Comm. on Energy \& Natural Res., 112 th Cong. (2011), http://perma.cc/2ZDM-FLFY; Shale Gas and Water Impacts: Hearing Before the Subcomm. on Water and Power of the S. Comm. on Energy \& Natural Res., 112th Cong. (2011), http:/ /perma.cc/V8BN-WVMC.

${ }^{88}$ See H.R. ReP. No. 111-316, at 109 (2009) (Conf. Rep.).

${ }^{89}$ Energy Policy Act of 2005, Pub. L. No. 109-58, 119 Stat. 594 (2005).

${ }^{90} 42$ U.S.C. $\S 300 \mathrm{~h}(\mathrm{~d})(1)$ (2012). As amended, SDWA's definition of "underground injection" now reads: "For purposes of this part ... the term 'underground injection'-(A) means the subsurface emplacement of fluids by well injection; and (B) excludes - . . (ii) the underground injection of fluids or propping agents (other than diesel fuels) pursuant to hydraulic fracturing operations related to oil, gas, or geothermal production activities." Id. The underground disposal of fracturing fluid remains regulated under the Act, but the initial injection of fluid during the "frac job" is unregulated unless diesel fuel is included in the frac fluid. Id.
} 
died quietly in committee. ${ }^{91}$ In 2013, Representatives Cartwright and Polis introduced the Focused Reduction of Effluence and Stormwater runoff through Hydrofracking Environmental Regulation ("FRESHER") Act,92 the Closing Loopholes and Ending Arbitrary and Needless Evasion of Regulations ("CLEANER") Act of 2013,93 and the Bringing Reductions to Energy's Airborne Toxic Health Effects ("BREATHE") Act, ${ }^{94}$ to close gas production loopholes in water, toxic waste, and air regulations, respectively. All three bills were referred to the Subcommittee on Water Resources and Environment, and as of November 2014, no further action had been taken. ${ }^{95}$

Federal agencies have been somewhat more proactive, at least in recent years. ${ }^{96}$ For example, the Bureau of Land Management ("BLM"), which oversees "700 million subsurface acres of Federal mineral estate and 56 million subsurface acres of Indian mineral estate," has proposed a rule to govern hydraulic fracturing operations on federal and Indian land. ${ }^{97}$ Among other things, that rule would require operators to (a) disclose the chemicals in their fracturing fluids; 98 (b) monitor cement integrity to ensure that wells are adequately sealed to prevent leakage; 99 (c) map expected rock fractures to ensure they do not threaten underwater aquifers; ${ }^{100}$ and (d) use lined pits to store wastewater from fracturing operations. ${ }^{101}$

EPA has undertaken the aforementioned study of drinking water impacts, ${ }^{102}$ announced a plan to develop wastewater effluent guidelines for oil and gas extraction, ${ }^{103}$ and initiated a process to obtain public input on what informa-

${ }^{91}$ See H.R. 1921, 113th Cong. (2013); S. 1135, 113th Cong. (2013); H.R. 1084, 112th Cong. (2011); S. 587, 112th Cong. (2011); S. 1215, 11 th Cong. (2009); H.R. 2766, 111 th Cong. (2009). ${ }^{92}$ H.R. 1175, 113th Cong. (2013). Bill tracking information for the FRESHER Act is available online at Congress.gov. H.R. 1175 - FRESHER Act of 2013, Congress.gov, http://perma.cc/ 4GT7-E6UQ.

${ }^{93}$ H.R. 2825, 113th Cong. (2013). Bill tracking for the CLEANER Act is available online at Congress.gov, H.R. 2825 - CLEANER Act of 2013, CongRESS.Gov, http://perma.cc/H63A-M3UB.

${ }^{94}$ H.R. 1154, 113th Cong. (2013). Bill tracking for the BREATHE Act is available online at Congress.gov, H.R. 1154 - BREATHE Act of 2013, CONGRESS.GOv, http://perma.cc/VU3X-LBLE.

${ }^{95}$ See supra notes 92-94 (bill tracking searches reveal no action as of November 2014).

${ }^{96}$ But see Hannah Wiseman, Untested Waters: The Rise of Hydraulic Fracturing in Oil and Gas Production and the Need to Revisit Regulation, 20 Fordham EnvtL. L. Rev. 115, 133-34 (2009) (noting that in a 2004 report, EPA somewhat questionably concluded that "the injection of hydraulic fracturing fluids into [coalbed methane] wells poses little or no threat to [underground sources of drinking water] and does not justify additional study at this time" (quoting EPA, Evaluation of Impacts to Underground Sources of Drinking Water by Hydraulic Fracturing of Coalbed Methane Reservoirs, ES-2 (2004), http://perma.cc/BW3A-HFTQ)).

${ }^{97}$ Oil and Gas; Hydraulic Fracturing on Federal and Indian Lands, 78 Fed. Reg. 31,636, 31,636 (proposed May 24, 2013) (to be codified at 43 C.F.R. pt. 3160).

${ }_{98} I d$. at 31,659 (explaining the disclosure requirement). To satisfy industry commenters that criticized an earlier version of the proposal, the current proposal includes broad exemptions for trade secrets. Id. at $31,659-60$.

${ }^{99} I d$. at 31,651-54 (explaining the cement monitoring and logging requirements).

${ }^{100} \mathrm{Id}$. at $31,648-49$ (requiring submission of map marked with estimated fracture direction, length, and height).

${ }_{101}$ Id. at 31,655 (detailing wastewater storage requirements).

102 See generally EPA's Study of Hydraulic Fracturing for Oil and Gas and Its Potential Impact on Drinking Water Resources, EPA, http://perma.cc/N4AQ-PGRZ.

${ }^{103}$ Natural Gas Extraction - Hydraulic Fracturing, EPA, http://perma.cc/MLV4-HECR. The proposed rule to amend the Clean Water Act effluent limitation guidelines for the Oil and Gas Extrac- 
tion about hydraulic fracturing chemicals should be reported under the Toxic Substances Control Act. ${ }^{104}$ In addition, the Agency has issued rules governing methane and hazardous air pollutant emissions from gas drilling sites. ${ }^{105}$

A few other federal agency efforts also bear mention: scientists from the National Oceanic and Atmospheric Administration ("NOAA") have been working with others at the University of Colorado to study atmospheric methane emissions around drilling sites; ${ }^{106}$ and the U.S. Department of State is engaged in an effort to share U.S. successes and failures in unconventional gas exploration, production, and risk mitigation to assist other countries that are beginning to exploit their own gas resources. ${ }^{107}$

Federal agencies are hamstrung, however, by the oil and gas industry's many longstanding exemptions from federal environmental and public health laws and regulations. The 2005 SDWA exemption affords a striking example, ${ }^{108}$ but there are several other areas in which Congress and the agencies have historically treated the industry with kid gloves. Decades ago, for instance, Congress and EPA chose to exclude oil and gas field wastes-which include natural gas drilling fluids and other production wastes-from the nation's "cradle to grave" hazardous waste handling, transport, storage, and disposal statute, the Resource Conservation and Recovery Act ("RCRA"). ${ }^{109}$ Likewise, until recently, EPA had declined to wield its Clean Air Act regulatory authority as aggressively as it might have. In 2007, the Bush Administration issued a memorandum interpreting preexisting EPA regulations to preclude aggregation of a single company's multiple, geographically dispersed gas wells into a single "major source" - a move that would have expanded the reach of the Clean Air Act's New Source Review and Title V permitting requirements. ${ }^{110}$ Less than three years later, the Obama Administration withdrew that memorandum and

tion Category is scheduled for publication later this year. See Unconventional Extraction in the Oil and Gas Industry, EPA, http://perma.cc/8XAC-LPY7.

${ }^{104}$ See Hydraulic Fracturing Chemicals and Mixtures, 79 Fed. Reg. 28,664 (proposed May 19, 2014) (to be codified at 40 C.F.R. ch. I).

${ }^{105}$ See Oil and Natural Gas Sector: New Source Performance Standards and National Emission Standards for Hazardous Air Pollutants Reviews, 77 Fed. Reg. 49,490 (Aug. 16, 2012) (to be codified at 40 C.F.R. pts. 60,63 ).

${ }^{106}$ Gabrielle Pétron et al., Estimation of Emissions from Oil and Natural Gas OperaTIONS IN NORTHEASTERN COLORAdo (2012), http://perma.cc/JK72-PQET.

${ }^{107}$ See generally Unconventional Gas Technical Engagement Program (UGTEP), U.S. DEP'T oF STATE, http://perma.cc/VMZ8-Q5XK.

${ }^{108}$ See infra notes $217-25$.

${ }^{109} 42$ U.S.C. $\$ 6921$ (b)(2)(A) (2012) (excluding "drilling fluids, produced waters, and other wastes associated with the exploration, development, or production of crude oil or natural gas or geothermal energy" from strict regulation under RCRA Subtitle C, pending a determination by EPA that such regulation was necessary); Regulatory Determination for Oil and Gas and Geothermal Exploration, Development and Production Wastes, 53 Fed. Reg. 25,446, 25,447 (July 6, 1988) (declining to make that determination). See generally James R. Cox, Revisiting RCRA's Oilfield Waste Exemption as to Certain Hazardous Oilfield Exploration and Production Wastes, 14 VILL. ENVTL. L.J. 1 (2003) (detailing the history of the exemption).

${ }^{110}$ See Memorandum from William L. Wehrum, Acting Assistant Adm'r, EPA, to Reg'l Adm'rs, on Source Determinations for Oil and Gas Industries (Jan. 12, 2007), http://perma.cc/EB28-56LY. See also Robin Bravender, EPA Tosses Bush-Era 'Aggregation' Policy for Oil and Gas Industry, N.Y. TIMEs (Oct. 14, 2009), http://perma.cc/7Q3U-KH2L (describing the memorandum). 
announced that it read the same regulations to allow such aggregation, provided the emissions stem from activities belonging to "the same industrial grouping[,] under control of the same" entity, and "located on one or more contiguous or adjacent properties." 111 The fate of that new interpretation remains uncertain, however, since at least one circuit has rejected it as inconsistent with the plain language of the preexisting regulations. ${ }^{12}$

Courts in some states with active gas production have also read the Migratory Bird Treaty Act narrowly to exempt permitted oil and gas operations from criminal liability for the death of migratory birds that land on wastewater ponds near gas wells. Recently, for example, the U.S. District Court for North Dakota held that "as a matter of law," the Act's criminal provisions do not extend to "lawful commercial activity which may indirectly cause the death of migratory birds." 113 The North Dakota decision contributes to an as-yet unresolved circuit split on the reach of the Act. ${ }^{114}$

Meanwhile, on the state level, a recent study of shale gas regulations in the twenty-seven states with active gas production ${ }^{115}$ found that while a few, such as West Virginia, have relatively comprehensive regulations, most regulate a much smaller subset of the relevant gas production issues. ${ }^{16}$ In addition, those state regulations that are in place have a variety of gaps. For example, while some fifteen states require that companies disclose the chemical ingredients in the fluid they inject, most such requirements make broad exemptions for trade secrets. ${ }^{117}$ Further, the study notes that states differ significantly in both their manner of regulating (command-and-control versus performance standards versus permitting) and the stringency of their enforcement measures. ${ }^{118}$ Finally, the authors complain of a lack of transparency: state requirements are hard to find and even harder to understand, particularly when they are not set out in generally applicable regulations, but incorporated in individual well permits. ${ }^{19}$

\footnotetext{
${ }^{111}$ Memorandum from Gina McCarthy, Assistant Adm'r, to Reg'l Adm'rs, Regions I-X, on Withdrawal of Source Determinations for Oil and Gas Industries (Sept. 22, 2009).

${ }^{112}$ Summit Petrol. Corp. v. EPA, 690 F.3d 733 (6th Cir. 2012).

${ }^{113}$ United States v. Brigham Oil \& Gas, L.P., 840 F. Supp. 2d 1202, 1213 (D.N.D. 2012).

${ }^{114}$ See United States v. Citgo Petrol. Corp., 893 F. Supp. 2d 841, 843-47 (S.D. Tex. 2012) (describing, and contributing to the split, and holding that "unprotected oil field equipment can take or kill migratory birds," giving rise to liability under the Migratory Bird Treaty Act (citation omitted)).

${ }^{115}$ The states in this category are: California, Utah, Montana, Colorado, Wyoming, New Mexico, North Dakota, South Dakota, Kansas, Nebraska, Oklahoma, Texas, Arkansas, Louisiana, Illinois, Indiana, Ohio, Kentucky, Tennessee, Mississippi, Alabama, Virginia, West Virginia, Maryland, Pennsylvania, and New York. Nathan Richardson et al., Res. for the Future, The State of State Shale Gas Regulation 25 (2013), http://perma.cc/VJ2L-F9CV.

${ }_{116}$ See id. at 43 (cataloging state disclosure rules).

117 Id; see also Matthew McFeeley, Natural Res. Def. Council, State Hydraulic Frac. TURING Disclosure Rules and ENForCEMENT: A COMPARISON 7 (2012), http://perma.cc/FDJ2HEZF (noting that eight of the states with existing disclosure requirements allow companies to withhold information they deem confidential without any justification or oversight, while only one state "has a clear process for evaluating and approving or denying trade secret exemption claims").

${ }^{118}$ RiChaRdSON ET AL., supra note 115 , at 13-21.

${ }^{119} \mathrm{Id}$. at $2-3,6$.
} 
Some limited natural gas governance efforts are also underway at the regional level. The Susquehanna River Basin Commission ("SRBC"), for instance, regulates water withdrawals from the Susquehanna River and its tributaries in three states-New York, Pennsylvania, and Maryland. While the SRBC does not regulate wastewater from hydraulic fracturing operations, it does restrict consumptive use of water for fracturing and imposes withdrawal moratoria when water levels are low. Further, the SRBC requires natural gas companies to abide by all other applicable state and federal water quality and waste management requirements, and helps to enforce those requirements by informing companies that failure to comply with other applicable laws can result in the modification, suspension, or revocation of SRBC's approval of a water-use request. ${ }^{120}$

The Delaware River Basin Commission ("DRBC") plays an even more active role in regulating hydraulic fracturing operations. The Commission manages "water quality, withdrawals, droughts, floods, conservation, and permitting" for the Delaware River and its tributaries in four states-Delaware, New Jersey, Pennsylvania, and New York. ${ }^{121}$ In 2010, the DRBC unanimously directed staff to develop draft hydraulic fracturing regulations through noticeand-comment rulemaking. ${ }^{122}$ Subsequently, however, the Commission postponed indefinitely its November 21, 2011 special meeting to consider the adoption of the regulations. ${ }^{123}$ In a July 10, 2013 statement, DRBC chair Michele Siekerka stated that the Commission is working to revise the regulations and updating them with current research, but she did not give a timeline for finalizing the current draft. ${ }^{124}$

Finally, numerous localities have gotten involved in the regulatory game. As of June 2014, some 423 localities nationwide (over 200 in New York alone) have attempted to use their zoning authority to ban hydraulic fracturing activities within their borders. ${ }^{125}$ That approach has prompted numerous preemption lawsuits. New York State's highest court recently held that zoning bans fit comfortably within New York localities' authority, ${ }^{126}$ but a West Virginia trial court found that state law preempted the City of Morgantown's ban. ${ }^{27}$ Existing Colo-

\footnotetext{
120 See generally FreQuently Asked Questions: SRBC's Role in Regulating Natural Gas Development, SusquehanNa River Basin Comm'N (2012), http://perma.cc/8797-J6CT.

${ }^{121}$ Delaware River Basin Commission: Battleground for Gas Drilling, STATEIMPACT, http://perma .cc/A495-J38D.

${ }^{22}$ See Natural Gas Drilling Index Page, Delaware River Basin Comm'n, http://perma.cc/ 6YLC-9LAR.

${ }^{123} \mathrm{Id}$.

${ }^{124} \mathrm{Id}$.

${ }^{125}$ See, e.g., Local Actions Against Fracking, FoOD \& WATER WATch, http://perma.cc/VM2JWEQL.

${ }^{126}$ See, e.g., Wallach v. Town of Dryden, 16 N.E.3d 1188, 1191 (N.Y. 2014), reargument denied, No. 2014-867, 2014 WL 5366261 (N.Y. Oct. 16, 2014) ("[New York] towns may ban oil and gas production activities, including hydrofracking, within municipal boundaries through the adoption of local zoning laws ... because the supersession clause in the statewide Oil, Gas and Solution Mining Law (OGSML) does not preempt the home rule authority vested in municipalities to regulate land use.").

${ }_{127}$ See Ne. Natural Energy, LLC v. City of Morgantown, No. 11-C-411, 2011 WL 3584376 (W. Va. Cir. Ct. Aug. 12, 2011).
} 
rado precedent points to a similar preemption outcome for pending lawsuits in that state. ${ }^{128}$

In sum, federal, state, regional, and local government entities are beginning to understand and address the variety of public health and environmental risks associated with the natural gas boom, but as yet there is nothing approaching a comprehensive public regulatory regime. The resulting gaps in governance have left ample room for private entities to take on such traditionally governmental tasks as promoting research, gathering and disseminating data, developing best practices, and assessing and certifying compliance with those practices.

\section{B. The Scope of Private Governance}

Numerous private entities are already undertaking these governance tasks, including national and regional environmental and public health groups, ${ }^{129}$ the collaborative or industry-led entities introduced in Part I, and various universities. ${ }^{130}$ In addition, there are also ongoing shareholder efforts to push particular publicly held companies to minimize "negative impacts from their hydraulic fracturing operations." 131

These players' activities fall into three basic categories: (1) information gathering and dissemination-collecting and publicizing information about the risks of unconventional gas drilling; (2) standards setting-developing and promoting a set of best practices to avoid identified risks of gas production; and (3) standards dissemination and implementation-encouraging and policing adoption of identified best practices. The remainder of the discussion in Part II illustrates these categories by reference to the work of the six entities introduced in Part I: API, ASTM International, CSSD, FracFocus, GAPP, and STRONGER.

\footnotetext{
${ }^{128}$ See generally Grace Hood, Historic Greeley Ruling Looms Large Over Colorado Fracking Challenges, NPR (Feb. 24, 2014), http://perma.cc/YK43-URJR (discussing the historic case of Voss v. Lundvall Brothers, 830 P.2d 1061 (Colo. 1992) (holding that Colorado's Oil and Gas Conservation Act preempted the home-rule City of Greeley from enacting a land-use ordinance that banned drilling for oil, gas, or hydrocarbons within the City)).

${ }^{129}$ See, e.g., Mark Zoback, Saya Kitasei \& Brad Copithorne, Worldwatch Inst., Addressing the Environmental Risks from Shale Gas Development 1 (2010), http://perma.cc/ L9XK-7N56; Natural Gas: Five Areas of Concern, EnvTL. Def. Fund, http://perma.cc/NA5S85 TK.

${ }^{130}$ The University of Colorado Law School's Getches-Wilkinson Center for Natural Resources, Energy, and the Environment, for example, created the Intermountain Oil and Gas BMP Project, which offers a free-access, searchable database of Best Management Practices ("BMPs") for oil and gas development in the Intermountain West. Intermountain Oil \& Gas BMP Project, Getches-Wilkinson CTR. For Natural Res., Energy, \& the Env'T, http://perma.cc/B7PN$352 \mathrm{G}$.

${ }_{131}$ Avery Fellow, Investors Demand Climate-Risk Disclosure in 2013 Proxies, Bloomberg (Feb. 25, 2013), http://perma.cc/6VQH-WYW2. See also Resolutions: Shareholder Resolutions, INVEStor Envtl. Health Network, http://perma.cc/FTR9-7XM6 (searching with subject filter "hydraulic fracturing").
} 


\section{Information Gathering and Dissemination}

FracFocus: Of the six entities identified above, only one, FracFocus, aims solely at information gathering and dissemination. FracFocus describes itself as a "national hydraulic fracturing chemical registry."132 Developed as a "joint project" 133 between two national quasi-governmental entities, the Ground Water Protection Council ${ }^{134}$ and the Interstate Oil and Gas Compact Commission, ${ }^{135}$ FracFocus aims to be a clearinghouse for information about the chemicals used in particular gas wells. Well operators are encouraged to self-report their drilling activity and chemical use, and members of the public can then view a map of the United States, find wells located in a particular geographic area, and reference a list of the chemicals used at those wells. As of November 2014, FracFocus identified 1,039 "participating companies"136 that had submitted data on over 85,000 wells. ${ }^{137}$

Of particular note, although FracFocus is a private enterprise, public legal regimes are increasingly identifying the registry, by name, as a platform for complying with public disclosure mandates. Of the eighteen states that have mandated that hydraulic fracturing companies disclose their chemical use, eleven now identify FracFocus as their chosen disclosure registry. ${ }^{138}$ Further, BLM's proposed rules identify FracFocus as a database that drillers on public lands may use to make required disclosures about various well characteristics, including location, depth, water use, and chemical use. ${ }^{139}$

\footnotetext{
${ }^{132}$ About Us, FRACFocus, http://perma.cc/QN6Q-4VKJ.

${ }^{133}$ FracFocus is Live, FRACFocus, http://perma.cc/QTL8-7DYS. For a discussion of the controversial origins of FracFocus, see generally Miriam Seifter, States as Interest Groups in the Administrative Process, 100 VA. L. Rev. 953, 1007-14 (2014).

${ }_{134}$ About Us, Ground Water Prot. Council, hittp://perma.cc/E3SK-LB52.

${ }^{135}$ About Us, InTERState OIL \& Gas COMPact CoMm'N, http://perma.cc/37SG-Z2UB.

${ }^{136}$ Participating Companies List, FRACFocus, http://perma.cc/4W68-W3XD.

${ }^{137}$ FracFocus 2.0, FracFocus, http://perma.cc/UE6X-LREE (showing "total well sites registered" as 85,659 as of November 15,2014 ).

${ }_{138}$ Mark Drajem, FracFocus Drillers' Registry to Create Chemicals Database, Bloomberg (May 23, 2013), http://perma.cc/6QMW-8E9S. See also Wiseman, supra note 25, at 53-54 (cataloging state disclosure rules). For an example of a statute mandating the use of FracFocus, see 16 TEx. Admin. Code \$§ 3.29(a)(8), (c)(2)(A) (2014) (defining the state's "Chemical Disclosure Registry" to be FracFocus, and then requiring that on or before a well completion report is submitted to the state commission, the operator of the well "must complete the Chemical Disclosure Registry Form and upload the form on the Chemical Disclosure Registry, including" information such as the total volume of water or other fluid used in the hydraulic fracturing of the well, and all "chemical ingredients used in the hydraulic fracturing treatment(s) of the well").

139 Oil and Gas; Well Stimulation, Including Hydraulic Fracturing, on Federal and Indian Lands, 77 Fed, Reg. 27,691, 27,693-94 (proposed May 11, 2012) (to be codified at 43 C.F.R. pt. 3160) ("For instance, the BLM is working closely with the Ground Water Protection Council and the Interstate Oil and Gas Commission in an effort to integrate the disclosure called for in this rule with the existing Web site known as FracFocus.").
} 


\section{Standards Development: An Introduction to the Players}

Other private governance entities are working to develop standards for natural gas production or standards for regulation of gas production-that is, a set of best practices for minimizing risks during drilling and extraction.

American Petroleum Institute: One of the most prominent standards-setting entities is the American Petroleum Institute, a trade association representing "all aspects of America's oil and natural gas industry." 140 API explains that its industry standards represent the "consensus" of experts and "go through a rigorous review process" 141 that incorporates familiar elements of administrative procedure, including notice and consideration of outside input. Indeed, the American National Standards Institute ("ANSI"), a private, nonprofit membership organization that (among other things) certifies that other private entities' procedures meet certain benchmarks for "openness, balance, consensus and due process," has approved API's standards development process. ${ }^{142}$ API's standards have considerable influence in the public sphere: "approximately $25 \%$, or 125 of API's 550 standards, are referenced in the U.S. Code of Federal Regulations," 143 and state oil and gas regulations and regulatory proposals also incorporate API standards. ${ }^{144}$

API has developed guidelines that "specifically address the risk management issues that accompany [the] construction and management" of shale gas wells, ${ }^{145}$ but it is not clear whether those guidelines conform to the ANSI's definition of "standards," nor whether API followed its ANSI-approved process in developing them. The guidelines are very specific and cover topics including (1) well construction and integrity, ${ }^{146}$ (2) water use and wastewater

\footnotetext{
${ }^{140}$ About API, Am. Petrol. Inst., http://perma.cc/V8XU-VH25.

${ }^{141}$ API, OVERVIEW OF INDUSTRY GUIDANCE, supra note 9.

${ }^{142}$ Domestic Programs (American National Standards) Overview, Am. Nat'L Standards Inst., http://perma.cc/GZK8-E4R2. Specifically, ANSI indicates that it reviews organizations' standardsdevelopment procedures to ensure, at a minimum, that those procedures allow for: "consensus on a proposed standard by a group or 'consensus body' that includes representatives from materially affected and interested parties;" "broad-based public review and comment on draft standards;" "consideration of and response to comments submitted by voting members of the relevant consensus body and by public review commenters;" "incorporation of approved changes into a draft standard;" and "right to appeal by any participant that believes that due process principles were not sufficiently respected during the standards development in accordance with the ANSI-accredited procedures of the standards developer." Id.

${ }^{143}$ Am. Petrol. Inst., American Petroleum Institute Standards 8 (2004), http://perma.ce/ B8P6-SS4R.

${ }^{144}$ In Pennsylvania, for example, surface casing cement must be "cement that meets or exceeds the ASTM International C 150, Type I, II or III Standard or API Specification 10." 25 PA. CoDE $\S 78.85$ (a) (2014). West Virginia requires that "[c]ement used to fill the annular space around the casing . . . be American Petroleum Institute Class A Ordinary Portland cement with no greater than three percent $(3 \%)$ calcium chloride and no other additives." $W$. V $V_{A}$. CoDE $R$. § 35-4-11.5 (2014).

${ }_{145}$ API, Overview of INDUSTRy Guidance, supra note 9.

${ }^{146}$ Am. Petrol. Inst., Guidance Document HF1: Hydraulic Fracturing Operations-Well CONSTRUCTION AND INTEGRITY GUIDELINES (2009) [hereinafter API, HF1], http://perma.cc/ KS8H-UQSS.
} 
management, ${ }^{147}$ and (3) surface impacts. ${ }^{148}$ Some of the guidelines appear neutral, technical, and objective. (For example, one guideline indicates "hydraulic fracturing equipment ... must be monitored for leaks and loss of integrity,"149 while another refers the reader to a preexisting API standard, RP90, to learn about maintaining a safe pressure at the wellhead. ${ }^{150}$ ) Conversely, other API shale gas guidelines reflect not broad consensus but instead the industry's political position on controversial policy issues: for example, one policy states, "[h]ydraulic fracturing should not be regulated under the Safe Drinking Water Act (SDWA) or any other federal statute. Since hydraulic fracturing has been successfully managed at the state level, it would be problematic, unnecessary and duplicative to have any additional requirements at the federal level." 151 An overview of API's relevant guidelines and standards is available in the Appendix.

American Society of Testing and Materials International: Founded in 1898 as the American Society for Testing and Materials, ASTM International is a voluntary, private standards-development entity. ${ }^{152}$ ASTM has long been a player in the environmental arena, and as with FracFocus, its work has migrated into public environmental law. To take just one related example, EPA regulations implementing the Comprehensive Environmental Response, Compensation, and Liability Act, allow owners of contaminated land to rely on ASTM due diligence standards to demonstrate eligibility for the so-called "innocent landowner defense."153

At present, ASTM International's natural gas standards are very much a work in progress. In 2012, the organization designated a committee, Subcommittee D18.26 on Hydraulic Fracturing, to draft consensus technical standards for natural gas production. ${ }^{154}$ ASTM anticipates that its standards will address a range of issues, including background site investigation, groundwater monitoring and remediation, and permanent well abandonment. ${ }^{155}$ The actual drafting process began in July 2013.156 A list of the topics that ASTM intends to include in its draft standards is available in the Appendix.

\footnotetext{
147 Am. Petrol. Inst., Guidance Document HF2: Water Management Associated with HyDRAUlic FRACTURING (2010), http://perma.cc/W3XJ-TVJA.

${ }_{148}$ Am. Petrol. Inst., Guidance Document HF3: Practices for Mitigating Surface Impacts Associated with Hydraulic Fracturing (2011) [hereinafter API, HF3], http://perma .cc/Y3MW-K3CS.

${ }_{149}^{14}$ Id. at 9.

${ }^{150}$ See API, HF1, supra note 146, at 22.

151 API, HF3, supra note 148 , at 8.

${ }^{152}$ See Overview, ASTM INT'L, http://perma.cc/E3PR-BB46.

${ }^{153}$ See 40 C.F.R. $\$ 312.11$ (2014). ASTM standards have also made their way into some state hydraulic fracturing laws. See, e.g., supra note 144.

${ }^{154}$ Doug Clauson, Hydraulic Fracturing: New ASTM International Subcommittee to Develop Needed Standards, ASTM Standardization News (Nov./Dec. 2012), http://perma.cc/LL7GY8CK.

${ }^{155} \mathrm{Id}$.

${ }^{156}$ See ASTM WK 42803 New Guide for Data Management and Reporting Associated with Oil and Gas Development Including Hydraulic Fracturing, ASTM INT'L, http://perma.cc/V6XMEK4W.
} 
Center for Sustainable Shale Development: The recently formed Center for Sustainable Shale Development offers a different model of private standards development. A "collaboration ... among environmental organizations, philanthropic foundations and energy companies from across the Appalachian Basin," CSSD aims to "develop[] rigorous performance standards for sustainable shale development" in that Basin, and to use an iterative review process to revisit and improve those standards as new information and technologies become available. The board of directors is quite inclusive, comprising representatives from three environmental groups, four natural gas production companies, a university, and a foundation, as well as several former government officials. ${ }^{157}$

CSSD's standards-development process is considerably further along than ASTM International's effort. As of October 2013, CSSD had identified fifteen "initial" standards, each with subparts, aimed at protecting "air quality, water resources and climate."158 The group pledged, however, that it would learn from the implementation of these fifteen standards and "adopt[ ] further innovations" and "revise [the] standards as appropriate." 159 The fifteen initial standards are available in the Appendix.

Gas and Preservation Partnership: A fourth private entity seeking to identify best practices for unconventional gas extraction is the fledgling Gas and Preservation Partnership. ${ }^{160}$ Like CSSD, GAPP seeks to bring together diverse stakeholders from nongovernmental organizations, universities, and industry. But GAPP seeks to address a different set of risks than CSSD-the risks to historic and cultural preservation (that is, the risks posed by drilling on or near Civil War battlefield sites, historic cemeteries, or Native American settlements, burial sites, or mounds). ${ }^{161}$ GAPP's website explains that it intends to "work collaboratively and pragmatically with both the energy industry and the preservation community to identify and properly manage historic and cultural resources while encouraging efficient exploration and development of energy reserves." 162 Specifically, the group aims to "devise, exchange, and verify implementation of model voluntary practices for the shale gas industry." 163 As of October 2014, however, GAPP had not yet issued draft practices.

State Review of Oil and Natural Gas Environmental Regulations: The fifth and final standards-development entity is the State Review of Oil and Natural Gas Environmental Regulations. Created by the public Interstate Oil and Gas Compact Commission with funding from EPA, the Department of Energy, and API ${ }^{164}$ STRONGER is a nonprofit collaborative with a diverse board that com-

\footnotetext{
${ }^{157}$ CTR. for Sustainable Shale Dev., http://perma.cc/RJ6T-LB6S.

${ }^{158}$ Performance Standards, CTr. For Sustainable Shale Dev., http://perma.cc/WXM9-52F8.

${ }^{159} \mathrm{Id}$.

${ }^{160}$ GAS \& PrEs. P'shiP, http://perma.cc/X2LA-KXZM.

${ }^{161} \mathrm{Id}$.

${ }^{162}$ GAPP's Mission, GAS \& PREs. P'shIP, http://perma.cc/TM9R-6FBD.

${ }^{163} \mathrm{Id}$.

${ }^{164}$ See About Us: Who We Are, State Review of Oil \& Natural Gas Envtl. Regulations, http://perma.cc/T6ZQ-K6E7 (describing the group's funding).
} 
prises representatives from environmental NGOs, the oil and gas industry, and state regulatory agencies. ${ }^{165}$

Unlike the other standards-development entities, STRONGER does not (primarily) aim to develop freestanding gas production standards, but instead to identify and then use gas production guidelines as a "yardstick by which to evaluate state [regulatory] programs, identify program strengths, and make recommendations for improvement,"166 STRONGER stakeholder "review teams" compare state oil and gas regulatory programs to STRONGER's guidelines, prepare a state "report card," and suggest regulatory improvements. ${ }^{167}$

That said, the first step in STRONGER's effort is, of necessity, the same as that for API and the other private standards organizations: the development of appropriate guidelines. STRONGER's development process involves multistakeholder review and consensus adoption. ${ }^{168}$ Developed in 2010 by a "hydraulic fracturing workgroup" (the composition of which is not disclosed on the group's website), ${ }^{169}$ STRONGER's guidelines for hydraulic fracturing suggest that state regulatory programs should cover risks ranging from well integrity, to groundwater monitoring and spill control, to public disclosure of the constituents of fracturing fluid. ${ }^{170}$ The complete guidelines are available in the Appendix.

\section{Standards Development: A Comparison of Ongoing Efforts}

The five standards-development entities' guidelines or best practices for hydraulic fracturing do not readily lend themselves to comparison because they are in various states of completion, use different terminology, and in some cases refer to entirely separate and previously published standards. That said, some broad observations are possible:

1. With the exception of GAPP's planned guidelines, which will focus on a different set of concerns, all of the identified guidelines or draft guidelines take a broad view of hydraulic fracturing risks that extends well beyond the "frac job" itself to encompass many of the pollution and safety risks identified in Part I.B above. ${ }^{171}$

\footnotetext{
165 See Our Team: Voting Members, State Review of Oil \& Natural Gas Envtl. RegulaTIONS, http://perma.cc/ENE7-J999.

${ }^{166}$ Memorandum from the STRONGER Board to Persons Interested in the Hydraulic Fracturing Guidelines (Feb. 8, 2010), http://perma.cc/H8XY-CN5F.

${ }^{167}$ See State Reviews: The Process, State Review of Oll \& Natural Gas Envtl. Regula. TIONS, http://perma.cc/Y8KT-YSMN.

${ }^{168}$ See State Review of Oll \& Natural Gas Envtl. Regulations, 2013 STRONGER GuideLINES $\$ 1.1$ (2013), http://perma.cc/H9YD-LYA8.

${ }^{169}$ The only reference to this "workgroup" appears in the guidelines themselves. See id.

170 See id. $\$ 9$.

${ }^{171}$ See infra Appendix.
} 
2. All of the groups strive to provide assurances that the guidelines or draft guidelines were or will be drafted with attention to process concerns, such as independence, transparency, and diversity of representation. ${ }^{172}$

3. On the other hand, none of the organizations offers an easy way to assess whether those process concerns have in fact been addressed. CSSD, for instance, indicates that its staff is "not associated with industry"; 173 that its funding sources are "diverse, coming from fees for evaluation services, philanthropy, and donations"; 174 that its board, which must approve all standards, comprises an equal number of "representatives of environmental organizations, industry, and the government, academic or other unaligned sectors"; 175 and that, over time, its standards will be amended "[w]ith input from operators, regulators, CSSD auditors, environmental groups and other stakeholders ... to ensure the [standards] continue to drive leading practices." 176 But CSSD does not provide outsiders the means to assess whether the standards development and amendment processes are in fact open or participatory, or the means to gauge how its staff plans to handle the inevitable disputes among those diverse stakeholders.

4. The fourth observation relates to a stark difference among the guidelines: they vary widely in their comprehensibility - an important characteristic if one is assessing the degree to which stakeholders outside of industry can meaningfully participate in development and amendment.

On one end of the spectrum, CSSD's guidelines are clear and concise, and they are phrased in aspirational terms and do not refer to particular technologies, so they can be readily understood by a reader with no technical background. For example, Standard 7.1 provides, "[o]perators shall design and install casing and cement to completely isolate the well and all drilling and produced fluids from surface waters and aquifers." 177

By contrast, many of API's guidelines are dense, technical, and largely incomprehensible to anyone outside the industry. For example, API HF1 Guideline 5.4 provides, "[a]ppropriate cement testing procedures should be properly carried out by the service company personnel (see API RP 10B-2). Cement slurry design should include testing to measure . . . slurry density; . . thickening time; fluid loss control; free fluid; compressive strength development; fluid compatibility (cement, mix fluid, mud, spacer)."178

${ }^{172}$ See id.

${ }^{173}$ Ctr. For Sustainable Shale Dev., CSSD Governance $\S$ II.A, http://perma.cc/E8TGLK6A.

${ }^{174} I d$.

${ }^{175}$ Id. § II. B.

${ }_{176}$ Performance Standards, supra note 158.

177 Ctr. for Sustainable Shale Dev., Performance Standards 4 (2013), http://perma.ce/ $3 \mathrm{YXV}-\mathrm{NKUQ}$.

${ }^{178}$ API, HF1, supra note 146 , at $7-8$. 
The contrast between these examples is clear, though its import is less so: on the one hand, CSSD's phraseology can be readily understood by a reader with no technical background; on the other hand, API's guidelines are much more comprehensive. Which approach is preferable likely depends on whether one assumes that industry is well meaning but needs detailed guidance (in which case one might prefer API's approach), or whether one instead assumes outside involvement is necessary to ensure that standards are rigorous and meaningful (in which case one would likely prefer CSSD's approach).

5. Relatedly, the guidelines differ in the degree to which they use performance standards versus directives to guide industry practice.

Many of CSSD's guidelines are phrased as performance standards. For example, Standard 1.1 provides that "[o]perators shall maintain zero discharge of wastewater (including drilling, flowback and produced waters) to Waters of the Commonwealth of Pennsylvania and other states."179

Other entities' guidelines take a more prescriptive approach. For example, API HF1 Guideline 7.3 suggests that, at a minimum, the surface drill pipe, or casing, is cemented in place at least 100 feet below the deepest underground drinking water source to minimize the potential for contamination. ${ }^{180}$

6. Finally, the groups' overall goals differ. CSSD aims to develop standards that "drive leading industry practices" and that "require[ ] a level of environmental performance that exceeds the regulatory minimums established by the states and the federal government." 181 API's goals are similar but slightly more modest: the group's best practices should "meet or exceed federal requirements while remaining flexible enough to accommodate the variations in state regulatory frameworks that often occur due to fundamental differences in regional geology and other factors." 182 STRONGER, by contrast, aims for outcomes: protecting "public health, safety, and the environment," and specifically in the natural gas context, "prevent[ing] the contamination of groundwater and surface water from hydraulic fracturing." 183

Part III revisits these similarities and differences in discussing the roles that private governance entities may play in the development of a comprehensive gas governance regime.

\footnotetext{
${ }^{179}$ Ctr. for Sustainable Shale Dev., supra note 177 , at 1 .

${ }^{180}$ API, HF1, supra note 146, at 11.

${ }^{181}$ Performance Standards, supra note 158.

182 Am. Petrol. Inst., Overview of Industry Guidance/Best Practices on Hydraulic FracTURING (HF) (2012), http://perma.cc/LM5N-XS39.

${ }^{183}$ State Review of Oil \& Natural Gas Envtl. Regulations, 2014 STRONGER Guidelines $\S \S 1.1,9.2$ (2014), http://perma.cc/TL2J-7EVV.
} 


\section{Standards Implementation and Enforcement}

Finally, private entities are also actively engaged in developing strategies for dissemination, implementation, and enforcement of identified best practices. As noted above, STRONGER is the only group whose principal aim is not merely to identify standards but to encourage their public adoption. States that have volunteered for STRONGER review submit their environmental regulatory programs to the organization, and its "stakeholder" teams evaluate and score the states' programs. ${ }^{184}$ STRONGER's principal innovation, then, is its decision to focus less on the criteria themselves and more on their implementation, through a deliberate and targeted effort to evaluate states' regulatory regimes and push reform where those regimes are inadequate to achieve the identified goals. Thus far, STRONGER indicates it has conducted six state reviews focused on hydraulic fracturing regulatory regimes. ${ }^{185}$

In addition to STRONGER, groups like FracFocus and CSSD, which are aimed principally at information disclosure and standards development, respectively, must also confront questions about standards dissemination, adoption, and verification. At this point, the standards are all so new that no statistics are available as to how many gas production operators have adopted any particular set of standards. As for questions of verification, the simplest option for a standards organization is to encourage voluntary adoption and permit self-reporting of compliance. As might be expected, however, research on voluntary environmental standards programs outside the natural gas context suggests that programs that require independent verification of compliance are more likely to improve participants' environmental performance than those that allow selfreporting. ${ }^{186}$

FracFocus and CSSD offer ready examples of these two alternative approaches. FracFocus provides an information disclosure platform but does not appear to conduct any in-house or third-party assessment of the completeness and accuracy of particular companies' disclosures (though of course individual states that use FracFocus as a disclosure platform can choose to add assessment procedures to their basic disclosure requirements). At the opposite end of the spectrum, CSSD is working to develop "an independent, third-party process to certify companies that achieve and maintain" the Center's standards. ${ }^{187}$

With that background, Part III situates these six entities' governance efforts in the broader context of private environmental governance theory.

\section{Private Environmental Governance Theory}

Until recently, much of the discussion around private entities engaged in activities that could be dubbed "environmental governance" concerned the ef-

\footnotetext{
${ }^{184} I d . \$ 1.1$.

185 See State Review of Orl \& Natural Gas Envtl. Regulations, supra note $168, \S 1.1$.

${ }^{186}$ See generally Darnall \& Sides, supra note 18.

${ }^{187}$ CTR. For Sustainable Shale Dev., supra note 157.
} 
ficacy of private systems of industry self-regulation. ${ }^{188}$ Over the last decades, though, scholars exploring more flexible and adaptive forms of "new governance" 189 have begun to recognize and explore the important ways that private organizations' efforts to develop and market innovative policy approaches can catalyze and advance-or, at times, stymie - the development of public or hybrid governance regimes. ${ }^{190}$ In brief, "[p]rivate governance could fill gaps where public governance cannot reach because of political, territorial, or expertise gaps. It also could undermine, enhance, delay, accelerate, or complement government action in situations where government can act."191

\section{A. The Hurdles Facing Public Environmental Governance}

This relatively new exploration of the synergies between private and public environmental governance has its roots in several other areas of scholarship,

188 See, e.g., Al Iannuzzi, JR., Industry Self-Regulation and Voluntary Environmental. COMPLIANCE (2002) (providing case studies of and benchmarking various industry self-regulatory programs, including the chemical industry's Responsible Care program and the EPA's now-defunct Project XL); Steinzor, supra, note 23 at 122-50 (providing a detailed case study and critique of Project XL).

${ }^{189}$ For a few of the many possible definitions of this term and collections of further references, see, for example, Jason M. Solomon, New Governance, Preemptive Self-Regulation, and the Blurring of Boundaries in Regulatory Theory and Practice, 2010 WIs. L. Rev. 591, 592-93, $594 \mathrm{n} .7$ (2010) (noting that "much of the literature . . . uses the term . . . to refer to a specific kind of regulatory approach, generally one with particular attributes such as benchmarking, transparency and democratic participation," but that the article uses the term "to describe a regulatory strategy or tool-or . . . as an "attitude'"); Bradley C. Karkkainen, "New Governance" in Legal Thought and in the World: Some Splitting as Antidote to Overzealous Lumping, 89 MINN. L. REV. 471, 474, 474-76 nn.13-25 (2004) ("[T] he New Governance model . . breaks with fixity, state-centrism, hierarchy, excessive reliance on bureaucratic expertise, and intrusive prescription. It aspires instead to be more open-textured, participatory, bottom-up, consensus-oriented, contextual, flexible, integrative, and pragmatic."); Orly Lobel, The Renew Deal: The Fall of Regulation and the Rise of Governance in Contemporary Legal Thought, 89 MinN. L. REv. 342, 371-404 (2004) ("The new governance model challenges . . . conventional assumptions. It broadens the decision-making playing field by involving more actors in the various stages of the legal process. It also diversifies the types of expertise and experience that these new actors bring to the table. [New] governance is a regime based on engaging multiple actors and shifting citizens from passive to active roles. The exercise of normative authority is pluralized.").

190 Some examples of this newer literature include Vandenbergh, supra note 7, at 170 (noting that to date few legal scholars have focused on private environmental governance and developing a model that "suggests that [while] private environmental governance is not a substitute for public governance ... it can fill temporal or other gaps in the public governance response to environmental issues," id. at 163); Sarah B. Schindler, Following Industry's LEED: Municipal Adoption of Private Green Buildings Standards, 62 FLA. L. REv. 285, 317-20 (2010) (discussing various models of local governance of green building design, from purely public to purely private); Heather Hughes, Enabling Investment in Environmental Sustainability, 85 IND. L.J. 597 (2010) (suggesting an amendment to Uniform Commercial Code Article 9 to facilitate-and thus incentivize-transactions that enable companies to improve their environmental practices); Meidinger, supra note 19, at 234 (discussing the role of private regulatory systems in ensuring food safety, and noting that "most private regulatory programs are . . . deeply intertwined with governmental and intergovernmental regulatory structures [and that] many have developed increasingly 'public' dimensions in that they seek to incorporate the concerns of all interested parties, operate with a high degree of transparency, and implement standards that claim to be in the public interest").

191 Vandenbergh, supra note 7, at 186. 
including the well-developed literature on the limitations of traditional regulatory law and of "laboratory federalism." 192 Though this Article does not attempt to provide a comprehensive overview of those roots, some background is helpful to contextualize the work of private gas governance entities.

Scholars-and, for that matter, informed citizens-have long understood that numerous barriers impede the promulgation of socially beneficial laws and regulations, in the environmental arena as elsewhere. Perhaps most familiar and accessible is the work of those public choice theorists who have used economic models to argue that public policy development is not wholly an altruistic enterprise, but instead a "competition between private interest groups for legislative influence." 193 In the administrative law context, the familiar term for the idea is "agency capture," which conveys that regulators may be unable to resist the influence of powerful interest groups that either oppose socially beneficial laws or promote laws that advance their own agenda at the expense of the public good. ${ }^{194}$

The now unremarkable fact that lobbyists and, in turn, government policymakers may act in self-interested ways is not, however, the only impediment to public-spirited environmental governance. Building on the work of prior scholars, Tracey Roberts discusses five stages of public governance-(1) agendasetting, (2) negotiation of standards, (3) implementation, (4) monitoring, and (5) enforcement-and identifies dysfunctions that can occur at each stage. ${ }^{195}$ She notes, for instance, that at the agenda-setting stage, barriers or imbalances in access to information (so-called "information failures") can stymie public entities' efforts even to identify, let alone decide, how to address the externalized social costs of particular industry activities. ${ }^{196}$ This problem is particularly acute in the environmental context because natural systems are enormously complex and nonlinear. ${ }^{197}$ As a result, causal pathways can be difficult to dis-

\footnotetext{
${ }^{192}$ See generally, e.g., Michael S. Sparer \& Lawrence D. Brown, States and the Health Care Crisis: The Limits and Lessons of Laboratory Federalism, in Health Policy, Federalism, and THE American States 181 (Robert F. Rich \& William D. White eds., 1996).

${ }^{193}$ Aziz Huq, Standing for the Structural Constitution, 99 VA. L. Rev. 1435, 1502 \& nn.272-77 (introducing public choice theory and collecting references).

194 See, e.g., Thomas W. Merrill, Capture Theory and the Courts: 1967-1983, 72 CHI.-Kent L. REv. 1039, 1050-52 (1997) (explaining capture theory); Richard Stewart, The Reformation of American Administrative Law, 88 HARV. L. REv. 1669, 1684-87 (1975) (discussing various reasons, other than overt "capture," why one might generally expect agencies to take a pro-industry stance).

${ }^{195}$ Roberts, supra note 15, at 77-78 (citing Kenneth W. Abbott \& Duncan Snidal, The Governance Triangle: Regulatory Standards Institutions and the Shadow of the Law, in THE Politics OF Global Regulation 43 (Walter Mattli \& Ngaire Woods eds., 2009)).

${ }^{196} \mathrm{Id}$. at 78 .

${ }^{197}$ Richard J. Lazarus, Restoring What's Environmental About Environmental Law in the Supreme Court, 47 UCLA L. REv. 703, 744-47 (2000) ("The primary source of this uncertainty is the sheer complexity of the natural environment and, accordingly, how much is still unknown about it. This uncertainty expresses itself in our inability to know beforehand the environmental impact of certain actions. It equally undermines our ability to apprehend, after the fact, what precisely caused certain environmental impacts.").
} 
cern-a problem that is compounded by the long latency period between many toxic exposures and resulting public health harms. ${ }^{198}$

At each subsequent stage of public environmental governance, additional hurdles arise. For one thing, lawmakers receive only a fraction of the benefits of the laws they enact, so they "have weak incentives to produce . . . legal innovations." 199 There are also the checks and balances deliberately introduced into our legislative (and regulatory) processes to slow the growth of government, ${ }^{200}$ as well as "the limits of jurisdictional boundaries," 201 ideological "preference[s] for small government," 202 and the challenges of funding and enforcing socially beneficial regulations. ${ }^{203}$

Shifting the focus away from any particular public governance effort to the functioning of our broader federal system exposes still other dysfunctions. Consider laboratory federalism - the idea, long heralded by courts, that one of the central advantages of our federal system is states' ability to function as policy "laborator[ies],"204 testing legislative and regulatory responses to new and imperfectly understood social problems "without dragging the whole country into the experiment." 205 "[S]everal crucial and successful national efforts originated in this way, including women's suffrage, unemployment insurance, . . . minimum wage laws," ${ }^{206}$ and now the move toward marriage equality. ${ }^{207}$ Indeed, there is a recent example in the environmental arena-California has been recognized as a "laboratory for the demonstration of cutting edge" technologies and policies to control greenhouse gas emissions. ${ }^{208}$

Yet there are, again, myriad barriers that may prevent the ideal of laboratory federalism from being realized on the ground. For one thing, because de-

${ }^{198}$ Id.

${ }^{199}$ Kobayashi \& Ribstein, supra note 21, at 522.

200 See, e.g., Steven G. Calabresi \& Livia Fine, Two Cheers for Professor Balkin's Originalism, 103 Nw. U. L. Rev. 663, 681-82 (2009) ("The Framers themselves made it quite clear that they designed the Madisonian system of checks and balances to prevent temporary passions, which might engulf the body politic, from being legislated immediately into law. They guaranteed . . . that change would be slow and incremental .....").

201 Vandenbergh, supra note 7, at 164.

${ }^{202}$ Id.

${ }^{203}$ Roberts, supra note 15 , at $68-69$.

${ }^{204}$ See, e.g., New State Ice Co. v. Liebmann, 285 U.S. 262, 311 (1932) (Brandeis, J., dissenting) ("It is one of the happy incidents of the federal system that a single courageous state may, if its citizens choose, serve as a laboratory; and try novel social and economic experiments without risk to the rest of the country.").

${ }^{205}$ David Snyder, Molecular Federalism and the Structures of Private Lawmaking, 14 IND. J. Global Legal Stud. 419, 431 (2007); $c f$. Barry Friedman, Valuing Federalism, 82 Minn. L. Rev. 317,398 (1997) (noting that the term "laboratories" may misleadingly suggest sterile or controlled trials, while "state experimentation is . . creative response to immediate necessity").

${ }^{206}$ Snyder, supra note 205 , at 431.

${ }^{207}$ See, e.g., Heather Elliott, Federalism Standing, 65 ALA. L. Rev. 435, 454 (2013) ("[The Court in Hollingsworth v. Perry, 133 S. Ct. 2652, 2660 (2013)] may have been vindicating federalism concerns more broadly by leaving the merits of marriage equality to the states for a while longer. Thus federalism interests do not tug only in the direction of protecting California's initiative system: the states more generally also may have an interest in working through issues of social policy as our fifty laboratories of democracy.").

${ }^{208}$ James E. McCarthy, Cong. Research Serv., RL34099, California's Waiver Request Under the Clean Air Act to Control Greenhouse Gases From Motor Vehicles 2 (2009). 
velopment of socially beneficial law is a classically under-produced public good, states "do not conduct experiments at the levels thought ideal by policymakers." 209 Risk- and cost-averse state regulators do not see adequate benefit in going first; they would prefer to wait and let other states take the regulatory lead. There is also the risk that states will engage in a "race to the bottom," competing not to have the most protective policies, but instead to attract industry with the most lenient and business-friendly regulatory regimes. ${ }^{210}$

Further, even when state experimentation occurs, there are impediments to the diffusion of successful policies, either horizontally (between states) or vertically (between a state and the federal government). The political impediments are straightforward-a policy that has been quite successful in, say, California may well be politically unpalatable in a central red state for that reason alone (and vice versa). But there are practical hurdles, too. Even when one state is innovating, it has neither an easy mechanism nor a strong incentive to share data about its policy successes and failures with other jurisdictions. ${ }^{211}$ A state's job is to govern, not to develop and market successful governance strategies for other states to adopt.

\section{B. The Hurdles in Context: Public Governance of Natural Gas Risks}

Illustrations of the hurdles impeding public environmental governance abound in the natural gas world. Information failures, for example, plague efforts to hold drilling companies responsible for water contamination near drilling sites. Populations that live in close proximity to new gas wells regularly

\footnotetext{
${ }^{209}$ Abbe R. Gluck, Federalism from Federal Statutes: Health Reform, Medicaid, and the OldFashioned Federalists' Gamble, 81 Fordham L. Rev. 1749, 1764 (2013) (citing Susan RoseAckerman, Risk Taking and Reelection: Does Federalism Promote Innovation?, 9 J. LeGaL STUD. 593, 594, 610-11 (1980); Edward L. Rubin \& Malcolm Feeley, Federalism: Some Notes on a National Neurosis, 41 UCLA L. Rev. 903, 925-26 (1994); David A. Super, Laboratories of Destitution: Democratic Experimentalism and the Failure of Antipoverty Law, 157 U. PA. L. Rev. 541 (2008)).

${ }_{210}$ See, e.g., Richard B. Stewart, Pyramids of Sacrifice? Problems of Federalism in Mandating State Implementation of National Environmental Policy, 86 YALE L.J. 1196, 1212 (1977) ("Given the mobility of industry and commerce, any individual state or community may rationally decline unilaterally to adopt high environmental standards that entail substantial costs for industry and obstacles to economic development for fear that the resulting environmental gains will be more than offset by movement of capital to other areas with lower standards."). But see generally Richard L. Revesz, Rehabilitating Interstate Competition: Rethinking the "Race-to-the-Bottom" Rationale for Federal Environmental Regulation, 67 N.Y.U. L. REv. 1210 (1992) (arguing that competition among states will produce an efficient allocation of industrial activity).

${ }^{211}$ See generally Hannah Wiseman, Regulatory Islands, 89 N.Y.U. L. REv. (forthcoming 2014) ("Sub-federal actors with regulatory or regulatory-type responsibilities, including stakeholder groups, municipalities, and states . . . often lack basic, comprehensive information about what other [such entities] are trying policy-wise, and it takes legal and policy experts years to collect and synthesize this information."); Brian Galle \& Joseph Leahy, Laboratories of Democracy? Policy Innovation in Decentralized Governments, 58 EMORY L.J. 1333, 1351 (2009) (noting that "good information" about other jurisdictions' innovations "may often prove elusive [because] innovators rarely have incentives to generate their own information, other actors may have limited knowledge about the most useful aspects of an experiment, and innovating jurisdictions may actually actively conceal information about their activities from outsiders").
} 
complain of flammable water that tastes strange and causes headaches. ${ }^{212}$ But little is known about the baseline quality of water in the area of many natural gas wells. ${ }^{213}$ Moreover, even drillers themselves are unable to predict with certainty where rock fractures will arise, and along what paths. As a result, industry has largely been free to dismiss claims of contamination ${ }^{214}$ while simultaneously preserving the information imbalance by declining to release information about what kinds of chemicals are in their proprietary "slickwater" mixtures. ${ }^{215}$

The resulting uncertainty around water contamination from natural gas wells has stymied public action to address the threat of contamination, for at least two reasons. First, even well-meaning public agencies have been hard pressed to figure out whether the contamination risks are real and, if so, which aspects of the drilling process require regulation and what forms that regulation should take. The ideal regulatory approach would be very different, for example, if one were convinced that water pollution stemmed from the fracturing of rock layers deep underground than if one instead believed the problem stemmed from inadequately lined wastewater ponds. Second, the difficulty in identifying and quantifying the risk to water sources and other public resources has made it challenging for public health and environmental advocates to counter industry assertions that the real social costs of hydraulic fracturing come not from drilling but from regulation of drilling, which limits job creation and thwarts economic development. ${ }^{216}$

Both legislative and regulatory capture are also evident in the natural gas world. The history of SDWA's sweeping exemption for the underground injection of fluids during hydraulic fracturing operations, ${ }^{217}$ for example, strongly hints of undue industry influence. As Hannah Wiseman documents, EPA first studied the need for SDWA regulation of hydraulic fracturing in 2004, reaching a conclusion starkly different ${ }^{218}$ from the Agency's current pro-regulatory stance $^{219}$ on the issue. Specifically, the Agency's 2004 report concluded that the risks of injecting "fracturing fluids into [certain] wells poses little or no threat to [underground sources of drinking water] and does not justify additional study at this time." 220 While EPA heard from a wide range of stakeholders prior to reaching this conclusion, there is evidence to suggest that industry-friendly

\footnotetext{
212 See, e.g., Gasland: the Movie (New Video Group 2010).

${ }^{213}$ See, e.g., Kate Galbraith, Strong Rules on Fracking in Wyoming Seen as Model, N.Y. Times (Nov. 22, 2013), http://perma.cc/5Y3X-BFVU.

${ }^{214}$ See, e.g., Steve Everley, How Anti-Fracking Activists Deny Science: Water Contamination, ENERGY IN DEPTH (Aug. 13, 2013), http://perma.cc/X4MK-9BPS.

${ }^{215}$ See How to Read a Fracturing Record, FracFocus, http://perma.cc/Z2FT-D3ZS (noting that even FracFocus allows companies to redact proprietary ingredients in their fracturing fluid).

${ }^{216} \mathrm{See}$, e.g., IHS Global InSight, Measuring the Economic and ENERgy ImPaCts of Proposals to Regulate Hydraulic Fracturing (2009), http://perma.cc/WZ8U-ELTW.

${ }^{217}$ For the text of SDWA, see supra note 90.

${ }^{218}$ See Wiseman, supra note 96 , at 180-82.

${ }^{219}$ See EPA's Study of Hydraulic Fracturing for Oil and Gas and Its Potential Impact on Drinking Water Resources, EPA, http://perma.cc/N4AQ-PGRZ.

${ }^{220}$ EPA, Evaluation of Impacts to Underground Sources of Drinking Water by Hydraulic Fracturing of Coalbed Methane Reservoirs ES-1 (2004), http://perma.cc/BW3A-HFTQ.
} 
interests may well "have had the upper hand" in molding the Agency's final conclusions. $^{221}$

On the legislative side, after EPA published its report, "industry vigorously used [the] results to lobby Congress. In October 2003, for example, the American Exploration and Production Council urged ... 'the 108th Congress [to] move quickly to pass" "the SDWA exemption for hydraulic fracturing. ${ }^{222}$ Moreover,

The Interstate Oil and Gas Compact Commission, a group of state regulators, called the legislation its own, stating, "President Bush signed into law the new energy bill this summer, which includes the IOGCC's proposal to resolve the hydraulic fracturing issue and brings several years of hard work by the Commission to fruition." 223

Plainly, "industry had a strong stake in both the outcome of the report and the legislation, and made its views on the matter clear." 224 And industry has also played a role in shaping some state disclosure laws that incorporate industryfriendly loopholes. 225

A final example of the impediments facing public gas governance concerns laboratory federalism. The recent report summarizing the state of state shale gas regulation ${ }^{226}$ illustrates that there are practical impediments to realizing courts' ideal of states as the originators and testers of policy innovations that eventually spread outwards and upwards, to other states and the federal government. Although states currently are experimenting with an array of different shale gas regulatory approaches, it is remarkably difficult for outsiders to discern either (1) the contours of a particular state's standards, or (2) how diligently and effectively the state is implementing and enforcing those standards. ${ }^{227}$ This opacity exists in part because many states incorporate well performance requirements in individual permits. ${ }^{228}$ As a result, even if a state has developed an innovative approach to well regulation, only the state regulators and the permit holder know of the approach, and there is little or no opportunity for regulators in other states to learn of it. ${ }^{229}$

\footnotetext{
${ }^{221}$ Wiseman, supra note 96 , at $180-82$.

${ }^{222}$ Id. at 181 (quoting a report from the American Exploration and Production Council).

${ }^{223}$ Id. (quoting IOGCC, Congress Passes IOGCC's Legislative Fix for Hydraulic Fracturing: Historical Overview, CoMPACT COMMENTs (2005), http://perma.cc/QXQ2-LTX3).

${ }^{224} I d$.

${ }^{225}$ Mike McIntire, Conservative Nonprofit Acts as a Stealth Business Lobbyist, N.Y. Times (Apr. 21, 2012), http://perma.cc/AP57-MU4F ("ALEC adopted model legislation, based on a Texas law, addressing the public disclosure of chemicals in drilling fluids used to extract natural gas through hydraulic fracturing .... The ALEC legislation, which has since provided the basis for similar bills submitted in five states, has been promoted as a victory for consumers' right to know about potential drinking water contaminants[, but a] close reading of the bill ... reveals loopholes that would allow energy companies to withhold the names of certain fluid contents .... [T] he bill was sponsored within ALEC by ExxonMobil, one of the largest practitioners of fracking . . . "). ${ }^{226}$ RICHARDSON ET AL., supra note 115.

${ }^{227}$ Id. at $2-3,6$.

${ }^{228} \mathrm{Id}$. at 10 ("[T] evaluate regulatory stringency and some other characteristics.").

${ }^{229}$ See generally Wiseman, supra note 211 (exploring this problem in a variety of contexts).
} 
A slightly different problem also stands in the way of successful laboratory federalism. Geologic and hydrogeologic conditions vary widely between states, so one state's successes may not readily translate to another area. More fundamentally, it may be difficult to assess the "success" of any particular state's regulatory regime. In Maryland, for example, policymakers are considering allowing hydraulic fracturing, subject to stringent regulations to mitigate risks. ${ }^{230}$ One measure of the on-the-ground impact of Maryland's proposed standards would be to evaluate whether they discouraged gas extraction activities in Maryland or, on the other hand, reduced the risks of those activities. Gas industry insiders indicate, however, that there is a very different reason why they may choose not to exploit Maryland's natural gas resources: Maryland's gas is "dry," meaning it contains fewer of the more lucrative liquid fractions (like butane and propane) that have drawn industry to shale plays in other states. As a result, the incidence of natural gas-related environmental or public health harms in Maryland may stay quite low for reasons unrelated to the efficacy of the state's regulatory policies. ${ }^{231}$

\section{Private Environmental Governance: A Partial Solution?}

Perhaps unsurprisingly, private governance entities readily surmount some of the hurdles that stand in the way of public environmental governance, such as the information and comprehension problems that plague any less technologically savvy public institution seeking to regulate a complex industry like natural gas production. On the other hand, numerous hurdles impede private governance-some that are familiar from the public governance world and some that are unique to private efforts. This section first explores the positive ways that private entities can contribute to mitigation of environmental risks and then turns to some of the hurdles.

To start with the positive, Tracey Roberts has noted that private entities may have better access to high quality information about the workings of the industry ${ }^{232}$ - particularly when the industry is as complex and technical as the oil and gas industry. Private entities' familiarity with the contours of industry practice, in turn, enables them to develop sophisticated platforms (like

\footnotetext{
${ }^{230}$ See Jonathan Wilson, Covepoint Serves as Flash Point for Maryland Debate over Fracking, NPR (July 11, 2014), http://perma.cc/L85J-R5UN.

${ }^{231}$ See id. (quoting Drew Cobbs from the Maryland Petroleum Council as observing that "in the end, they probably will recommend going forward with fracking in Maryland, with safeguards. And from what I've seen and where things stand right now, Maryland will by far have the strictest and tightest regulations in place if we do go forward with fracking" and characterizing him as holding the view that "it's not even clear who will want to drill in Maryland ... . [because] Maryland's deposit is mostly dry gas . . . so it's not worth as much [and the state's] regulations may be so strict that it won't be worth it for companies to drill [there]").

${ }^{232}$ See Roberts, supra note 15, at 109-12 (discussing the role of private "disclosure and reporting initiatives" in addressing information asymmetries).
} 
FracFocus $)^{233}$ to gather industry information. Finally, these entities may be better situated to understand the incoming information and assess its accuracy. ${ }^{234}$

Private policy-development efforts also need not obey jurisdictional boundaries nor appeal to any particular political constituency. As a result, these private efforts "can be segmented, and then infinitely and constantly rearranged to meet particular and changing needs. Private lawmaking is literally boundless, in that it is not tied to geographical boundaries. And it is flexible: private lawmaking can adapt to different situations in different ways." 235

The work of a group like CSSD provides a helpful illustration of this point. CSSD aims "to support continuous improvement and innovative practices through performance standards and third-party certification" for shale development efforts in the Appalachian Basin. ${ }^{236}$ It may well be that natural gas standards must be tailored to local conditions, as Merrill and Schizer argue, ${ }^{237}$ but the relevant "locality" is likely to be defined by geological and hydrological (and climatic and political) conditions, not state boundaries. Because of this, federal efforts to address natural gas pollution might fail to account for conditions in Appalachian Basin states, while state regulatory efforts would be thwarted by the inability to develop a cooperative regime that works equally well across the whole Basin. CSSD has no such concerns-it can develop standards for its basin of interest without regard to political boundaries and then focus its political efforts on incentivizing industry to adopt those standards.

Indeed, incentivizing industry adoption of environmental standards plays to private entities' strengths because privately developed standards may appeal to industry in a way that public regulation never can. Privately developed environmental standards may serve a variety of business-friendly purposes, including: (1) pricing smaller, noncompliant competitors out of the market; ${ }^{238}$ (2) serving as a baseline for reasonable care in the industry, and thereby protecting compliant industry players from tort liability; ${ }^{239}$ (3) improving the industry's image with consumers; ${ }^{240}$ and (4) reassuring regulators that the industry itself is

\footnotetext{
${ }^{233}$ See supra text accompanying notes $132-39$.

${ }^{234}$ See Roberts, supra note 15, at 109-11.

${ }^{235}$ Snyder, supra note 205 , at 433.

${ }^{236}$ About the Center For Sustainable Shale Development, CTR. fOR Sustainable Shale Dev., http://perma.cc/G2Q9-PQLL.

${ }^{237}$ See Merrill \& Schizer, supra note 32, at 151-52.

${ }^{238}$ See David V. Snyder, Contract Regulation, With and Without the State: Ruminations on Rules and Their Sources. A Comment on Jürgen Basedow, 56 AM. J. Comp. L. 723, 729 (2008) ("By erecting an elaborate regime to which all serious market players must adhere, a group can certainly achieve anticompetitive effects .... [S]ome industry players may seek to have their rules imposed on other industry players-not to raise barriers to entry, but to gain a competitive advantage over a rival that will have to change the way it does business.").

${ }^{239}$ See Rachel Saltzman, Establishing a "Due Care" Standard Under the Lacey Act Amendments of 2008, 109 Mich. L. Rev. First Impressions 1, 6 (2010) ("In products liability suits, compliance with trade or industry custom often provides meaningful evidence for a party defending against a negligence claim. Similarly, compliance with procurement standards, rating systems, or certification programs intended to address illegal logging should provide meaningful evidence of due care under the Lacey Act.").

${ }^{240}$ See, e.g., IANNUZZI, JR., supra note 188, at 26 (noting that some companies adopt self-regulatory initiatives "because they are aware of consumers' concerns for the environment"); see also
} 
addressing all of the important safety concerns and need not be further regulated. ${ }^{241}$ Again, the facts in the natural gas world speak for themselves on this point: the same industry players that publicly tout the safety of hydraulic fracturing, ${ }^{242}$ and oppose federal regulation of natural gas drilling, ${ }^{243}$ are front and center on the list of supporters of API, ASTM, CSSD, and GAPP's standardsdevelopment efforts. ${ }^{244}$

A separate point about private governance relates to private entities' role in policy dissemination-that is, in the broader diffusion of successful policy strategies. A state may have neither the resources nor any reason to publicize how it achieved its policy successes. Indeed, if one accepts the idea that states use their policy innovations to compete for a highly mobile citizenry, ${ }^{245}$ then a successful state regulatory innovation is akin to a newly developed, but not yet patented technology - the state has every incentive to tout (or perhaps even exaggerate) its policy success but little reason to explain the details of its policy. By contrast, private organizations have the ability and the incentive to market their successful policy innovations-whether information databases or standards or regulatory strategies-to industry players, the public, and regulators at all levels of government. The incentive arises because these organizations are, of necessity, externally rather than internally focused. They exist to promote their information platforms, environmental standards, or regulatory strategies to industry players or regulators, either as a direct source of revenue (if they charge for use of their information platform or sell published standards guides) ${ }^{246}$ or as a selling point for fundraising (if they seek public funding or

\footnotetext{
Vandenbergh, supra note 7, at 167 (explaining that this consumer-driven pressure to "green" industry practices can be larger than one might expect, because (1) if the greening can be done efficiently, "the additional cost to the consumer of the substitute good or of not purchasing a good may be small," and further, (2) even though consumers may not be willing to pay much more for green goods, "firms also respond to more generalized concerns about firm or brand reputation"). ${ }^{241}$ Roberts, supra note 15, at 74 (citing David Vogel, The Private Regulation of Global Corporate Conduct, in The Politics of Global Regulation 151, 159, 167-68 (Walter Mattli \& Ngaire Woods eds., 2009)).

${ }^{242}$ See, e.g., Reuters, Shell President: Fracking Safe, YouTube (July 7, 2011), http://perma.cc/ TW6Z-MTT8.

${ }^{243}$ See id.; see also API, HF3, supra note 148, at 8 ("Hydraulic fracturing should not be regulated under the Safe Drinking Water Act (SDWA) or any other federal statue. Since hydraulic fracturing has been successfully managed at the state level, it would be problematic, unnecessary and duplicative to have any additional requirements at the federal level.").

${ }^{244}$ See supra text accompanying notes 140-70 (discussing the sponsors of these private governance entities); see also Strategic Partners, CTR. For Sustainable Shale Dev., http://perma.cc/ K4EE-W8LF.

${ }^{245}$ Daniel Abebe \& Aziz Huq, Foreign Affairs Federalism: A Revisionist Approach, 66 VAND. L. REv. 723, 765-66 (2013) (noting that "subnational units . . have an incentive to compete for populations," and citing Jonathan A. Rodden, Federalism, in THE OXFORd HANDBOOK OF POLITICAL ECONOMy 357, 360 (Barry R. Weingast \& Donald A. Wittman eds., 2006) (defining "competitive federalism" as the idea that "under decentralization, a government must compete for mobile citizens and firms, who sort themselves into the jurisdiction that best reflects their preferences for bundles of governmental goods and policies")).

${ }^{246}$ ASTM, for example, publishes an Annual Book of ASTM Standards, made up of more than eighty volumes, that is available for sale at the Society's online bookstore, http://perma.cc/C6FEEMMK.
} 
donations from concerned citizens). ${ }^{247}$ As a result, private governance entities may overcome some of the practical impediments to information diffusion and thus to laboratory federalism.

In fact, some private governance entities are perfectly situated to improve laboratory federalism because they are designed to encourage state policy experimentation and to catalyze the subsequent dissemination of successful public policy innovations. STRONGER, for instance, surveys and assesses the success of the various state risk-regulation approaches. As described above, ${ }^{248}$ STRONGER first promotes its suite of regulatory options to states and then returns with a state report card and suggestions for improvement. To date, STRONGER has only reviewed hydraulic fracturing regulations in six statesArkansas, Colorado, Louisiana, Oklahoma, Ohio, and Pennsylvania ${ }^{249}$-and its recommendations are fairly narrow and targeted. ${ }^{250}$ With only a slight shift in its operating model, though, the organization could first identify and then promote the spread of effective regulatory approaches, by helping states determine which sister-state approaches are more (or less) successful in practice and under what conditions. In other words, STRONGER could serve Wiseman's critical (but presently underperformed) function of maintaining a clearinghouse of information on state laws and industry performance standards, "[t]o assist states in identifying the best regulatory options, ... remind the laggards of areas where improvement is needed and demonstrate the many variations in risk response."251

Yet there are important caveats to this rosy view about the workings of private governance entities. First, private governance regimes face a compliance conundrum. As noted earlier, such regimes sometimes rely on voluntary reporting to assess compliance. Yet, participants may seek to derive the benefits of nominal participation without actually improving their performance. ${ }^{252}$ This problem can persist even after the privately generated approach is adopted into public law, if the public law regime lacks a robust compliance-assessment protocol or has limited funds to assess compliance.

For an information-gathering entity like FracFocus, for example, the challenge is to encourage voluntary, honest, and complete disclosure of information about drilling practices. Several factors may limit or bias disclosures. First, as noted above, companies may be concerned about giving up a competitive advantage by disclosing (allegedly) proprietary information, such as the identity and quantity of the compounds in the slickwater used for hydraulic fractur-

\footnotetext{
${ }^{247}$ Snyder, supra note 238 , at 730 .

${ }^{248}$ See supra notes $164-70$ and accompanying text.

${ }^{249}$ Past Reviews, State Review of Oil \& Natural Gas Envtl. Regulations, hitp://perma.cc/ 32BR-A5DW.

${ }^{250}$ See, e.g., State Review of OtL. \& Natural Gas Envtl. Regulations, Colorado Hydrau. lic Fracturing State Review 6 (2011), http://perma.cc/U6AH-72S3 (recommending that the Colorado Oil and Gas Conservation Commission "consider whether establishing a maximum surface casing depth may be in order to prevent well control or cementing problems").

${ }^{251}$ See Wiseman, supra note 30, at 179.

${ }^{252}$ See generally Darnall \& Sides, supra note 18.
} 
ing. ${ }^{253}$ Second, with respect to non-proprietary information, while companies may have an incentive to disclose information that paints them in a positive light, they have no incentive to disclose inculpatory or otherwise damaging information about their practices. Third, some useful information-such as baseline surface water and groundwater quality prior to drilling-may be expensive to obtain. Companies are unlikely to invest in this research if they have any reason to fear that the resulting information will be used against them in court. Finally, even if there is some public pressure to disclose, the public is likely to be satisfied with partial disclosures. This is the central conundrum of an information imbalance-the party in the know can buy considerable goodwill by disclosing some information, while the less-well-informed party can never be sure she is receiving true and complete answers to her questions.

In the absence of additional requirements, FracFocus gives participating companies the ability to tout their transparency without guaranteeing that their disclosures are complete and accurate. ${ }^{254}$ As a result, some "disclosures," which refer only to hydraulic fracturing chemicals' brand names and not their "proprietary" ingredients or reactive properties, are more notable for what they hide than what they reveal. 255

A second limitation to private governance is that private entities are by no means immune to the problems that plague public governance. Indeed, as Bruce Kobayashi and Larry Ribstein have argued, beneficial private governance may itself-somewhat ironically_amount to an under-produced public good, because private entities cannot fully realize the economic or reputational benefits of their efforts. ${ }^{256}$

For example, an entity like CSSD, which works to develop best practices for hydraulic fracturing, may try to promote its standards to industry as a shield against future tort liability. ${ }^{257}$ Yet CSSD cannot guarantee that result, precisely because its standards are voluntary. An industry defendant could point to its conformance to CSSD's standards as evidence that it took "due care," but it probably could not argue that its conformance to those standards preempted its tort liability (as the mere existence of state or federal regulatory requirements

${ }^{253}$ See How to Read a Fracturing Record, supra note 215.

${ }^{254}$ In practice, an individual state could choose to utilize FracFocus but also to make third-party verification a part of its disclosure mandate.

${ }^{255}$ See, e.g., Snyder Bros., Inc., Hydraulic Fracturing Fluid Product Component Information Disclosure, Robert A Zaborowski \#1M-47.5 Well, API \# 37-019-21822, Fracture date 7/24/2012, FracFocus, http://perma.cc/WMW9-ZMAY (disclosing the use of "iron control," "scale control," and "acid corrosion inhibitor," but providing little additional information about the properties or "proprietary" components of those additives).

${ }^{256}$ Kobayashi \& Ribstein, supra note 21 , at 525. But see Vandenbergh, supra note 7 , at 166-70 (explaining that "[s]everal attributes" of private certification and labeling systems have made it relatively easy for such systems to overcome the "second-order collective action problem" that could, in theory, dissuade private entities from developing functioning private governance regimes).

${ }^{257}$ See Saltzman, supra note 239, at 6. 
sometimes does 258 ). CSSD could, of course, attempt to increase the legal import of its standards by pushing states or federal agencies to codify them-but on that front, the group would likely run into significant political opposition from industry, which may well have supported the standards precisely because they were advertised as an alternative to, rather than a model for, government regulation. Further, if some government entity did adopt CSSD's standards, the group would lose its "intellectual property rights in [its] creations"259 - and, in turn, lose at least some ability to profit from those creations, either directly (through charging for standards manuals or for performance evaluations) or indirectly (through charitable donations).

Moreover, private governance entities also face an issue of scale. Several authors have suggested that shale gas regulation is best undertaken at the state or local level, in part because shale gas risks vary with the geology and geography of the drilling site, which requires regulatory efforts to be "tailored to local conditions." 260 This raises concerns for both public and private efforts to develop best practices, but the problem is most severe for private entities, which take advantage of shared interests across regulatory jurisdictions-an advantage that loses its import if standards must vary with local conditions. In other words, the more one believes that unconventional gas extraction policy must be developed by entities familiar with local geography and geology, the less of an advantage large and geographically unconstrained private organizations have in developing that policy.

Private governance entities may also lack adequate incentives to revisit and refine their chosen approach. They are nimble and quick to innovate, but having innovated, they may prove even more resistant to policy change than public entities, which are driven to revisit past policy choices every election cycle. For example, FracFocus quickly appeared on the scene and developed its information platform, but has been slow to respond to critiques of that platform. The problem is even greater if the private governance approach creates reliance interests that make participating industry players resistant to change or modification of the existing scheme. ${ }^{261}$ In the case of a privately developed standards regime, for example, standards intended to provide a floor might quickly become a ceiling, discouraging the development of improved practices and technologies to reduce gas risks.

\footnotetext{
${ }^{258}$ See generally Catherine M. Sharkey, Products Liability Preemption: An Institutional Approach, 76 Geo. WASH. L. Rev. 449, 454-76 (2008) (surveying Supreme Court jurisprudence on regulatory preemption).

${ }^{259}$ Kobayashi \& Ribstein, supra note 21, at 525.

${ }^{260}$ Merrill \& Schizer, supra note 32, at 151. See also Spence, supra note 77, at 492-93, 508.

${ }^{261}$ On the other hand, some authors have suggested that if the private governance scheme is created and administered by an entity separate and distinct from the industry - such as a trade association-the association might have incentives to revise and refine the rules even if the industry players oppose that renovation, because each time the association updates the rules, it generates a new product (the revised rulebook) that it can market to its industry members. Snyder, supra note 238, at 730 (offering a hypothetical scenario in which the standard-setting organization's interests would favor rule revisions even "at the expense of [organization] members").
} 
Further, there is an argument that some of the same factors that could be used to attract industry support for privately developed standards could, conversely, make industry players wary about participating in a voluntary standards-development effort in the first place. For example, industry players may be concerned that the effort will result in standards (1) that immediately become the baseline for "due care" in the industry, ${ }^{262}(2)$ that banks and insurance companies adopt as prerequisites for provision of financial loans or liability insurance, ${ }^{263}$ or (3) that states adopt and render binding. Indeed, it appears that CSSD may have encountered this reluctance in attempting to build a broad coalition of strategic partners to support the Center's standards development work. Thus far, only four of the top ten production companies operating in Pennsylvania have agreed to work with the Center. ${ }^{264}$ Others were invited to join, but declined. ${ }^{265}$ STRONGER, too, faces buy-in problems: states may not choose to undergo review in the first place, and even when they do, they have no obligation to adopt all of the review team's recommendations. ${ }^{266}$

Another problem with private governance relates to process. Privately developed standards raise issues of openness, fairness, and accountability, particularly if there is a risk that industry players may seek to use the standardsdevelopment process to advance anticompetitive interests, or if the industry hopes to use compliance as evidence that its practices meet some externally defined social goal (such as the promotion of environmental sustainability, worker safety, or fair labor conditions). ${ }^{267}$

${ }^{262}$ See, e.g., Merrill \& Schizer, supra note 32, at 201-28; Maxwell J. Mehlman, Professional Power and the Standard of Care in Medicine, 44 ARIz. ST. L.J. 1165, 1224 (2012) (criticizing proposals to use medical practice guidelines as "safe harbors" to insulate physicians from malpractice liability).

${ }^{263}$ Many global banks, for example, have adopted the Equator Principles, "a set of environmental assessment and disclosure requirements" that apply to project finance borrowers that seek loans over ten million dollars. Vandenbergh, supra note 7, at 151. "Project finance lending by [Equator Principle] member banks [now] accounts for more than $70 \%$ of global project finance lending in developing countries." $1 d$. at 152.

${ }^{264}$ Kevin Begos, Center for Sustainable Shale Development Fracking Coalition Upsets Environmentalists, Drillers, HuFFINGTON PoS'T (Apr. 7, 2013), http://perma.cc/3QFV-SV64.

${ }^{265}$ Kevin Begos, Fracking Coalition Upsets Both Greens and Drillers, AP (Apr. 7, 2013), http:// perma.cc/LYK6-FJV5.

${ }^{266}$ As of July 2013, the STRONGER website indicated that STRONGER teams had reviewed and critiqued twenty-two state programs; "[d]uring the summer of 2009 , all states that ha[d] been reviewed were surveyed to determine the status of implementation of [STRONGER's] recommendations ... . Of the 593 recommendations to the 16 states that responded, 194 (33\%) were described as fully implemented, $161(27 \%)$ as partially implemented, $157(26 \%)$ as outstanding and $82(14 \%)$ as unknown." State Reviews: The Process, State Review of OIL \& Natural Gas ENVTL. Regulations, http://perma.cc/Y8KT-YSMN.

${ }^{267}$ See, e.g., Jason Morrison \& Naomi Roht-Arriaza, Private and Quasi-Private Standard Setting, in THE OXFord HANDBOOK OF INTERNATIONAL ENVIRONMENTAL LaW 498, 520 (Daniel Bodansky et al. eds., 2007) (noting, for example, that " $[t]$ here is . . . an inherent tendency for private standards to be, overall, less stringent than public ones covering the same subject matter"); Freeman, supra note 23, at 642 (noting that historically, "[l]arger firms tended to exert a disproportionate influence over standards that often ensured favorable treatment for their products"); James W. Singer, Who Will Set the Standards for Groups That Set Industry Product Standards?, 12 NAT'L J. 721 (1980). 
There is no way to measure the reality of industry capture, of course, but standards developed by an industry-dominated private entity are likely to hew closely to the industry's preferred approach, at some expense to more publicly oriented ideas. Even more concerning is that this can happen even if the private group is committed to avoiding policy capture. As Wendy Wagner has demonstrated in the context of agency rulemaking, for example, the Administrative Procedure Act's provisions that require agencies to involve the public in policy development had the "unintended consequence[ ]" of creating "information capture":

[A] continuous barrage of letters, telephone calls, meetings, followup memoranda, formal comments, post-rule comments, petitions for reconsideration, and notices of appeal from knowledgeable interest groups over the life cycle of a rulemaking can have a "machine-gun" effect on overstretched agency staff. . . . To make matters worse, as the issues grow more numerous and technical, less well-financed interest groups find it hard to continue participating in the process. ... Yet as their engagement wanes, so does the pluralistic engine considered so fundamental to the administrative process. They can no longer provide a means of culling out extraneous information and other chaff from the rulemaking through their vigorous engagement. ${ }^{268}$

Worse still, Wagner continues, "[u]nlike the older conceptions of capture that depend fundamentally on the vulnerability of the hearts, minds, and stamina of agency staff to special interests, information capture flourishes even when agency officials are determined to resist this pressure."269

In the context of private governance, the problems of ideological and informational capture are compounded by the public perception of bias. The industry players in the natural gas world are so large and wealthy, and their incentives so clearly aligned toward resource development, that as soon as industry takes a seat at the table, the public is likely to perceive the entire private governance effort as irreversibly tainted. The Sierra Club, for example, dubbed CSSD's efforts to develop guidelines " 'akin to slapping a Band-Aid on a gaping wound,' and a coalition of grass-roots groups . . . claimed that [any plan developed by the Center would] 'simply put[ ] green lipstick on a pig." "270 As a result, even if a private governance entity attempts to reduce industry influence by involving outside groups in its policy development effort-as ASTM International has tried to do-it may have trouble attracting such groups to the table.

And that is not the only hurdle that stands in the way of process reforms. For one thing, even large NGOs that are well staffed and amply funded to

${ }^{268}$ Wendy E. Wagner, Administrative Law, Filter Failure, and Information Capture, 59 Duke L.J. 1321,1325 (2010).

${ }^{269}$ Id. at 1326.

${ }^{270}$ Begos, supra note 264. 
weigh in on public rulemaking efforts may encounter staffing and funding limitations that restrict their ability to follow the myriad activities of private industry groups and respond to each group's proposed standards. Then too, public process may be cost-prohibitive for the private governance entity itself. The very act of opening decisionmaking to public process (and perhaps even adding some sort of back-end process by which interested parties could appeal compliance determinations or ask the entity to revisit or revise its standards, as interested parties can now petition agencies to reconsider rules) would tie private entities in knots. Decisions that can now be made quickly and nimbly with the backing of membership would drag on for decades just as controversial agency rulemakings now do. ${ }^{271}$ In other words, increasing the transparency and objectivity of private entities' decision-making processes might well destroy the very advantage these entities now have over their public counterparts.

Indeed, these observations about the challenges facing any effort to reform private entities' governance procedures may help explain why, although "many standard-setting organizations have taken steps to ensure compliance with due process, and have opened their meetings to public view," 272 others continue to "appear secretive, industry-dominated, and rife with the potential for anticompetitive behavior."273

\section{Interactions Between Private and Public Gas Governance}

Gas governance entities illustrate the developing theory of private environmental governance, including both the promise and pitfalls of relying on private solutions to serious public risks. In addition, though, the entities offer a window into the ways that private governance efforts can either foster or impede the development of successful public governance regimes. Specifically, on the positive side, such entities can serve as a "means of experimenting with policy options ... at low risk to policymakers,"274 or of strengthening "legality verification" and thereby supplementing otherwise inadequate public enforcement. ${ }^{275}$ On the negative side, however, private entities may compete for limited advocacy dollars and time, or dilute public demand for government efforts to mitigate risks. ${ }^{276}$

\footnotetext{
${ }^{271}$ See, e.g., Michael D. Sant'Ambrogio, Agency Delays: How a Principal-Agent Approach Can Inform Judicial and Executive Branch Review of Agency Foot-Dragging, 79 GEo. WASH. L. REv. $1381,1384-85$ (2011) (documenting lengthy delays in agency action).

${ }^{272}$ Freeman, supra note 23, at 642. As Freeman notes: "[ASTM] has become a pseudoagency, with 'balanced' committees and sub-committees comprised of representatives with different interests whose responsibility is to draft standards, a central staff to monitor their work, and an appeals process to ensure compliance with procedures. Undeniably, technical committees still frequently fail to include sufficient consumer, small business, and labor interests, and committees may continue to be driven primarily by economic concerns, but they have moved in the direction of openness and balanced representation." Id.

${ }^{273}$ Id.

${ }^{274}$ Vandenbergh, supra note 7 , at 188.

${ }^{275}$ Id. at 162.

${ }^{276} \mathrm{Id}$. at 187.
} 
Assessing the degree to which API and the other private gas governance entities may be contributing to these positive or negative "spillover effects" 277 on public governance is a difficult task, particularly at this early stage in the development of gas governance. As a first step in that assessment, this Part supposes an ideal model for public gas governance-specifically, a cooperative federalism regime, along the lines suggested by Professor Jody Freeman and others $^{278}$ - and then considers whether private gas governance efforts are moving us closer to that ideal. Importantly though, the purpose of this Article is not to advocate for a cooperative federalism regime, nor to suggest that private governance entities are more likely to promote cooperative federalism than any other public regime. Rather, this Article is simply using cooperative federalism as one of many possible public governance "targets," and then attempting to assess whether the plethora of private gas governance entities seem likely to bring us closer to or farther from that hypothetical end target.

The basic outline of a cooperative federalism regime is as follows: (1) the federal government sets minimum requirements, preferably in the form of general "performance standards," such as "zero discharge," that require the achievement of a specified degree of risk reduction; (2) the states then have the primary role in implementing those standards, or even choosing to exceed them; but (3) the federal government can step in if states fail to achieve the national minima. In the natural gas context, the federal government could set standards for, e.g., information disclosure, drilling site identification (including groundwater testing), well construction, water consumption, and wastewater treatment. As Professor Freeman notes, ${ }^{279}$ a cooperative federalism program like this exists in many familiar environmental laws, including-most relevant to the natural gas context - in the Surface Mining Control and Reclamation Act of 1977.280

The below discussion first details the ways that private governance entities have already advanced or could advance progress toward a cooperative federalism regime for natural gas governance. Part IV.B then considers some ways that these entities could impede such progress or, perhaps worse, taint the eventual regime.

\section{A. The Positive Story}

The most significant roles that private entities can play in advancing the goal of a cooperative federalism regime are to (a) collect information about natural gas risks; (b) help catalog the risks; (c) identify alternative production practices (in the form of a list of "best practices") that would reduce the risks; (d) assist in creation and adoption of federal standards (either directly or by

\footnotetext{
${ }^{277} I d$.

${ }^{278}$ See Freeman, supra note 82.

${ }^{279}$ Id.

${ }^{280} 30$ U.S.C. $\$ \S 1201-1328$ (2012).
} 
smoothing public opposition to such a move); and (e) assist in state implementation of those standards (again, either directly or indirectly).

Taking on many of these tasks requires two traits that, thus far, federal and most state governments appear to lack: (1) the ability to act on these contentious issues without raising the ire of either the electorate or the industry (or in spite of that ire); and (2) a deep understanding of existing industry practices, the risks posed by those practices, and the availability and efficacy of alternative approaches. As noted above, private entities have already been quite successful in collecting information on shale gas risks and in developing standards to address those risks. These successes suggest that such entities are less hamstrung than government officials by the political debates around gas development.

FracFocus, for example, has made great strides in information collection. Presumably, the website has had this success in part because it offers an entirely voluntary disclosure platform and does not review or police those disclosures in any way. Disclosing drilling practices on FracFocus is thus a win-win for industry players-they can tout their openness and earn public goodwill while continuing to keep business information confidential, all without exposing themselves to any kind of regulatory penalties for incomplete or inaccurate compliance. ${ }^{281}$

The next step in development of a cooperative federalism regime is to use the newly gathered information about the industry to identify a workable (that is, cost-effective) set of national performance standards. Here, too, private entities have a head start. As private governance theory explains, groups like API, ASTM, CSSD, and GAPP are well positioned to get out ahead in the development of gas extraction standards. Take API, for example: the Institute has been in the business of developing standards for decades, and its members, including many of the largest oil and gas companies, ${ }^{282}$ know the industry inside and out. Moreover, as noted above, unlike government entities, industry trade groups like API may have the affirmative support of their membership when they work to identify a suite of gas extraction best practices, whether because voluntarily adopted standards can price non-compliant competitors out of the market or because such standards insulate against command-and-control regulation. ${ }^{283}$

Indeed, as noted above, industry might well suppose that a privately developed set of standards would provide some protection against federal or state adoption of contrary or more stringent standards. Any federal or state actor who discovers that standards and/or a compliance regime already exist in the private

\footnotetext{
${ }^{281}$ See Mike Soraghan, Hydraulic Fracturing: FracFocus Straining Under Heavy Use as BLM Weighs Disclosure, ENERGYWIRE (Sept. 6, 2013), http://perma.cc/87CA-PP6H ("An industry group, the Independent Petroleum Association of America, stressed its support for FracFocus even as it said the rule [requiring disclosures] was duplicative and unnecessary. 'FracFocus strikes the proper balance between substantial disclosure of additives used in hydraulic fracturing operations and protection of trade secrets service suppliers develop to improve the quality and safety of those operations,' wrote IPAA's Dan Naatz and Kathleen Sgamma.").

${ }^{282}$ API Member Companies, AM. Petrol. Inst., http://perma.cc/MH2A-9E7M.

${ }^{283}$ See supra notes $238-44$ and accompanying text. See also, e.g., Strategic Partners, CTR. FOR Sustainable Shale Dev., http://perma.cc/K4EE-W8LF.
} 
sector is likely to favor public adoption of the privately developed system over development of new public standards for at least two reasons. First, the difficult work of political buy-in has already been done. Second, the privately developed standards may come with a built-in compliance regime, whereas newly developed standards would require the jurisdiction to develop its own standards and then develop and fund its own inspection and enforcement procedures. Indeed, the White House Office of Management and Budget expressly supports federal adoption of existing private standards "to eliminate costs associated with development of new standards" and "to work toward harmonization of standards." "284 This policy should reassure industry actors that if they support creation of a privately developed sustainability program, they are unlikely to be blindsided by federal adoption of some inconsistent set of standards.

At the same time, the private governance players in the natural gas world are well situated to facilitate adoption of private standards by public entities. STRONGER, in particular, is deliberately set up to help states strengthen their regulation of oil and gas practices. ${ }^{285}$ If STRONGER were interested in promoting the standards that underlie a particular, privately developed standardized regime, it could simply use those standards as its guidelines for evaluating existing state practices. States whose existing practices paralleled those that underlie the regime would receive a good report from STRONGER; those whose regulations diverged from the regime would receive suggestions from STRONGER about how to bring their regulatory programs in line with that regime.

As noted above, states would also have an added incentive to conform: conformity would enable them to use the privately developed program and its independent verification protocol as a hassle-free and relatively cheap method of assessing industry's compliance with the state standards. Further, the involvement of industry-backed private entities like API could reduce the political backlash for states that choose to adopt the standards developed or endorsed by that entity. If, later, numerous states were on board with one set of such standards, that interstate harmony would ease the process of pushing through the uniform federal standards that form the backbone of a cooperative federalism regime. Finally, STRONGER could also ease other states' later implementation of those federal standards by using its state review process to help identify and spread successful and cost-effective state implementation strategies.

\section{B. Negative Spillover Effects}

There are also reasons to be concerned that private governance efforts could negatively impact development of a cooperative federalism regime. First, there is a risk that the sheer proliferation of privately developed standards could slow or even thwart development of a single set of national standards. As noted

${ }^{284}$ Schindler, supra note 190 , at 314 .

${ }^{285}$ See supra notes $164-70$ and accompanying text. 
above, ${ }^{286}$ the private standards under development in the natural gas world vary widely. But in the absence of a market-which can arise for some kinds of product standards ${ }^{287}$ — private governance efforts have no means of jockeying for position. They can experiment with standards development, but they lack any means to assert that their standards should take precedence over any other entity's standards. Each set of standards is likely to have a set of NGO, industry, and perhaps also state backers, and this factionalization may make it difficult for interest groups and policymakers to agree to back any one set of standards for national adoption.

The form of the various privately developed standards could also create problems for anyone working to develop a cooperative federalism regime. Such regimes are most effective if the national minima take the form of performance standards-for example, CSSD's recommendation that "[o]perators shall design and install casing and cement to completely isolate the well and all drilling and produced fluids from surface waters and aquifers." 288 National performance standards like this one give each state the necessary flexibility to develop technically varied implementation strategies that best reflect climatic, hydrologic, geologic, and perhaps also economic and political conditions in the state. Yet, some of the private gas governance groups are developing technically specific standards that require the use of a particular technology or adherence to a specified drilling approach. If the eventual national standards took this more directive form, there would be little remaining room for states to realize performance improvements and cost savings by developing individualized implementation strategies.

A different set of negative spillover effects relates to the process used by private groups to develop their information platforms or drilling standards. Concerns about the process of private standards development are most pressing, of course, when government entities adopt the standards as binding public law-either expressly or by reference. ${ }^{289}$ In that context, the legitimacy of the resulting public standards depends in large part on the private standards body's ability to "meet various criteria of transparency, democracy, notice, . . . an opportunity for voice and exit, and [some guarantee that the body is] not dominated . . . by the regulated industry." ${ }^{290}$ As noted above, some private groups have begun to make procedural reforms to increase transparency, openness, and

\footnotetext{
${ }^{286}$ See supra Part II.B.3.

287 See generally, e.g., Snyder, supra note 238.

${ }^{288}$ CTR. FOR Sustainable Shale DeV., supra note 177 , at 4.

${ }^{289}$ For a discussion of the particular concerns raised when standards are incorporated by reference, see, e.g., Peter L. Strauss, Private Standards Organizations and Public Law, 22 WM. \& MARY BILl RTS. J. 497, 498 (2013). "Simplified, universal access to law is one of the important transformations worked by the digital age . . . Lagging behind this development, however, has been computer access to standards developed by private standards development organizations, often under the umbrella of the American National Standards Institute (ANSI), and then converted by agency actions incorporating them by reference into legal obligations. To discover what colors the Occupational Safety and Health Administration (OSHA) requires for use in work-place caution signs, one must purchase from ANSI the standard OSHA has referenced in its regulations, at the price ANSI chooses to charge for it." Id.

${ }^{290}$ See Schindler, supra note 190 , at 317.
} 
fairness, but there are reasons to question the efficacy of these reforms, and some groups remain quite insular and at least potentially biased toward the interests of their members. ${ }^{291}$

Finally, the contours of developing private governance regimes may distort the eventual public regime. Borrowing a term from a different environmental governance context, this can be described as a "problem of fit." ${ }^{292}$ Because private organizations' goals may differ somewhat from those of public officials in particular jurisdictions, an information platform or set of standards developed by a private entity may be excessively or insufficiently restrictive when adopted without modification as a solution to a public governance problem. FracFocus offers a ready example: its off-the-shelf disclosure platform cannot be individually tailored to match each state's on-the-books disclosure requirements. Thus, one author concludes that the "[u]se of FracFocus . . . appears to reduce compliance with some state reporting requirements," because the website "contains [data] fields for only a very limited subset of the information that state disclosure rules [purport to] require." ${ }^{293}$ Another notes that FracFocus does not solicit such seemingly important information as the distance from the gas well to surrounding - and hence at-risk-surface waterbodies. ${ }^{294}$ States that use FracFocus as their platform for information collection lose the opportunity to collect this information, which may in turn limit their ability to address wellto-surface water contamination. ${ }^{295}$ Moreover, states that use FracFocus may find themselves at the mercy of the company's technical and business decisions, ranging from upgrades or other modifications of the platform, to decisions about where and for how long to store companies' data, to choices about whether to charge fees for access and even whether to stay in business.

\section{CONCLUSION}

Federal, state, and regional governments' slow response to the risks of unconventional gas extraction has created a conspicuous governance gap and an opportunity for private governance entities to proliferate and innovate. These entities' real-time efforts offer a case study for the developing theory of private

\footnotetext{
${ }^{291}$ See Freeman, supra note 23. See also supra notes 272-73 and accompanying text.

${ }^{292}$ Oran R. Young, The Institutional Dimensions of Global Environmental Change: Fit, INTERPLAY, AND SCALE 20 (2002).

${ }^{293}$ MCFeeley, supra note 117 , at 8 (emphasis added). See also KATE KonschNiK ET AL., Harvard law Sch. Envtl. Law Program Policy Initiative, Legal Fractures in Chemical Disclosure laws: Why the Voluntary Chemical Disclosure Registry FracFocus Fails as a Regulatory Compliance ToOl (2013), http://perma.cc/4KHH-9U9L.

${ }^{294}$ Wiseman, supra note 25 , at 66 .

${ }^{295}$ On the other hand, Hannah Wiseman has noted that lawmakers can sometimes use their influence to induce changes in private governance regimes. "Colorado, for example, provides that if by 2013 FracFocus 'does not allow the Commission staff and the public to sort the registry for Colorado information by geographic area [and various other characteristics,]' or 'there is no reasonable assurance that the registry will allow for such searches,' then operators must [instead] use electronic forms created by the Colorado Oil and Gas Conservation Commission." Id. at 54 (quoting 2 Colo. Code Regs. § 404-1:205A(b)(3)(A), (B) (2012)). In theory at least, the potential loss of influence that this would cause may convince FracFocus to modify its private disclosure approach.
} 
environmental governance. On the one hand, one can understand private entities as fulfilling the information collection and policy experimentation roles once assigned to states. The efforts of FracFocus, API, STRONGER, and the other private entities at work in the natural gas world partially support this model. These entities have been able to act quickly to develop and promulgate the information platforms and risk mitigation standards so conspicuously absent from federal and most state regulatory regimes.

At the same time, these entities' efforts illuminate the serious shortcomings of private governance, some of which become particularly obvious when one evaluates the work these organizations could do to advance progress toward adoption of a public governance regime, such as a cooperative federalism regime. First, the entities offer the possibility of paper compliance without the assurance of enforcement-so called "greenwashing." Second, their work may distort rather than complement or enhance the development and operation of federal and state regulatory regimes.

Third, unless the groups are careful to open their efforts to balanced representation, their work is likely to suffer from industry bias, which may be difficult to surmount in the private context. Even large and wealthy public interest groups that are well structured to participate in public rulemakings are unlikely to be staffed and funded to participate equally in private governance efforts. Moreover, perceived bias may deter outside groups from participating in private governance efforts even if they are invited to do so. No matter what process reforms private entities undertake, therefore, they may not hear from a representative sample of outside interests.

Finally, there is a serious problem of scale: on the one hand, if the particular nature of the problem requires that standards be tailored to local conditions, then private groups may lose their procedural advantage. On the other hand, if the ultimate goal is to move toward national uniformity, then the absence of a widely accepted rule to identify the supremacy of any particular set of private standards could well prove fatal to private governance efforts. 
APPENDIX

Privately Developed Natural Gas Standards

Overview of API standards for hydraulic fracturing: http://perma.cc/LTU7HFPF.

Proposed new ASTM standards for hydraulic fracturing:

- New Guide for Sampling and Analysis of Residential and Commercial Water Supply Wells (WK42923): http://perma.cc/4JTM-WL55.

- New Test Method for Determining the Crush Resistance of Materials Used as Proppants in Hydraulic Fracturing of Subsurface Formations (WK44896): http://perma.cc/P5XT-L5KW.

- New Test Method for Standard Test Method for Dynamic Image Analysis of Natural Sand, Resin Coated Sand, Ceramic and Other Manufactured Materials Used as Proppants (WK42600): http://perma.cc/7K59Q62V.

- New Guide for Data Management and Reporting Associated with Shale Oil and Gas Hydraulic Fracturing Operations (WK42803): http://perma .cc/96E4-3T8V.

CSSD performance standards for hydraulic fracturing: http://perma.cc/ Y6M6-Q78U.

STRONGER hydraulic fracturing guidelines: http://perma.cc/64L-LMBJ. 